\title{
Geochemistry and Petrogenesis of Dioritic-Gabbroic Pegmatites in the Bulfat Complex, Qala Diza, Northeastern Iraq
}

\author{
Shareef T. Al-Hamed \\ Department of Geology \\ College of Science \\ University of Mosul
}

\author{
Khalid J. Aswad \\ Department of Geology \\ College of Science \\ University of Mosul
}

\author{
Nabaz R. Aziz \\ Department of Geology \\ College of Science \\ University of Sulaimaniya
}

(Received 22/8/2020 ，Accepted 21/11/2020)

\begin{abstract}
The pegmatite dikes and associated plutonic rocks stand as a part of the igneous complexes associated with the Bulfat complex, located in the Zagros Suture Zone (ZSZ), NE Iraq. The Bulfat complex is a part of the ophiolite-bearing terranes that are allochthonous sheets. The complex represents the upper allochthon of the AlbianCenomenian. The study area is located within Bulfat complex of ZSZ, specifically in the northwestern part of this zone and within the second unit of the Penjween-Walash Subzone. The rock samples were collected from pegmatite dike which is located to the northeast of the Darishmana village, the thickness of dike is about $5 \mathrm{~m}$.

Electron microprobe analyses (EMPA) of plagioclase in 8 spots of dioritic pegmatites ranges between oligoclase (An18.00-An28.23) and andesine (An32.53An33.62). Bulk whole-rock chemical analysis of fourteen samples using ICP-MS analysis reveals alkalinity Index (AI) of pegmatites to be metaluminous $(\mathrm{A} / \mathrm{NK}>2)$. Generally, the silica content in these pegmatites is from $46.70 \mathrm{wt}$. \% to $52.67 \mathrm{wt}$. \%

The relatively flat pattern of REEs is characterized by the slight enrichment of LREEs compared to HREEs indicating the common ancestry of the studied pegmatites. Also, the enrichment of these pegmatites in LILEs ( $\mathrm{Sr}, \mathrm{Pb}, \mathrm{Rb}$ ) and depletion in HFSEs especially $(\mathrm{Nb}, \mathrm{Ta}, \mathrm{Y})$ indicate the environment of the island arcs. Moreover, the low ratios of $(\mathrm{Rb} / \mathrm{Sr}) \mathrm{N}$ and $(\mathrm{Ba} / \mathrm{Sr}) \mathrm{N}$ refer to that these pegmatites are derived from a basic origin.

Tectonic discriminate diagrams show that the tectonic environment of studied pegmatites is I-type, which is the oceanic island arcs environment of sub alkaline rocks. The pegmatites of the present study have a genesis relationship with intrusions close to them in the study area; these intrusions are gabbros of Wadi Rashid that represent the environment of E-MORB. Moreover, the gabbros of Wadi Rashid and studied pegmatites are part of ophiolite-bearing terranes, they are found within upper allochthon thrust sheet. The current study of pegmatites reflects the oceanic island arcs environment, this indicates the existence of double island arcs, the first adjacent to the Arabian shelf, and the second close to the middle of paleo-ridge.

Numerous evidences support that the gabbros of Wadi Rashid being as the likely parent to the studied pegmatites such as geochemistry, tectonogenesis, and the close spatial distribution of the pegmatites to the gabbros of Wadi Rashid. Moreover, the
\end{abstract}


studied pegmatites appear to entail further dissection mainly due to the fact that the occurrence of dioritic- and gabbroic-pegmatites with a small-scale in the single intrusion might have its explanation in the liquid associated immiscibility.

Keywords: Bulfat complex, Gabbroic pegmatite, Geochemistry, Petrogenesis.

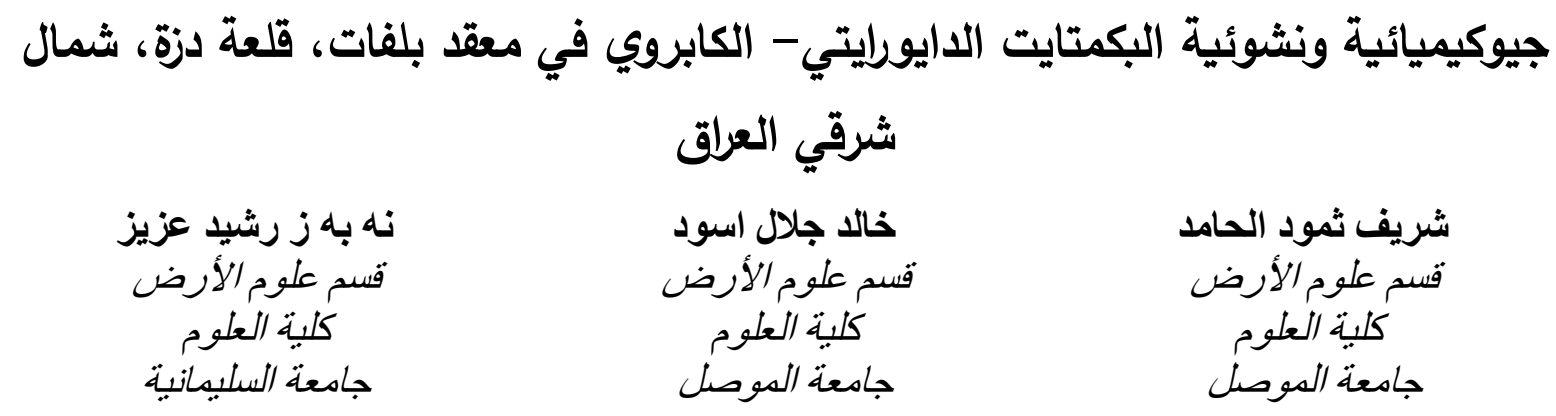

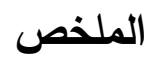

تُعد القواطع البكمتايتية والصخور الجوفية المرتبطة بها جزءاً من المعقدات النارية المرتبطة بمعقد بلفات

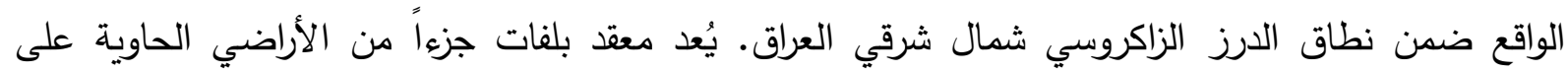

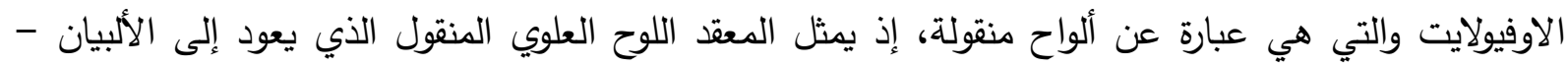

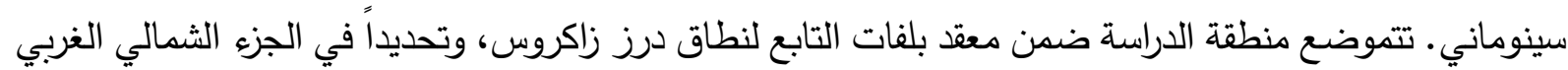
من هذا النطاق وضمن الوحدة الطولية الثانية من نطاق بنجوين - والاش الثانوي. جمعت النماذج الصخرية من الثنان قاطع بكمتايتي يقع شمال شرقي قرية دارشمانه، ويصل سمك هذا لطن القاطع الى 5 م تقريباً.

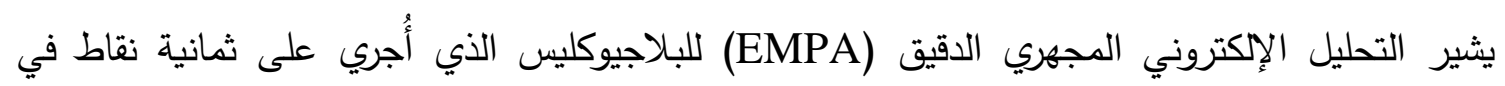

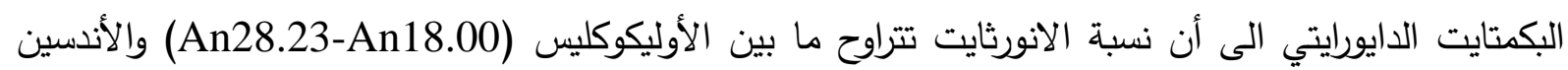

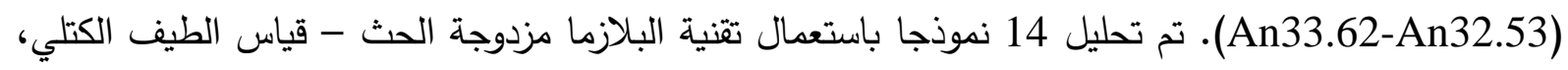

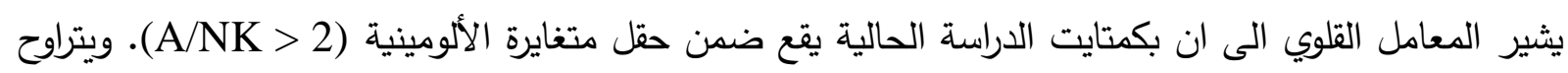
محتوى السليكا في هذا البكمتايت بشكل عام من 46.70 وزناًاء الى لى 52.67 وزناًاء. النمط المتوازي نسبياً للعناصر الأرضية النادرة المتميز بالإغناء في العناصر النادرة الخفيفة مقارنةً بالثقيلة

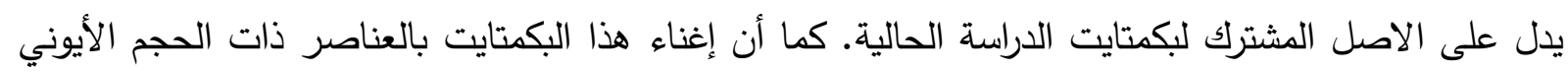

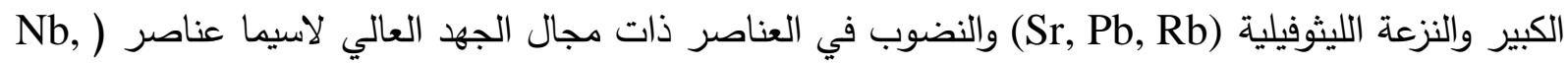
(Ta, Y أن هذا البكمتايت مشتق من أصل قاعدي.

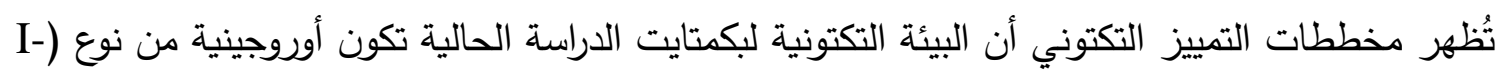

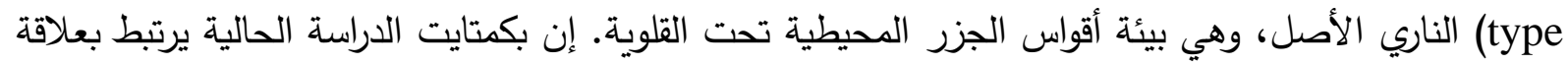

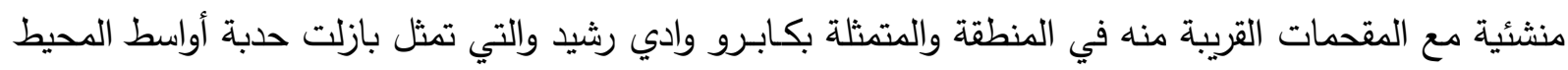




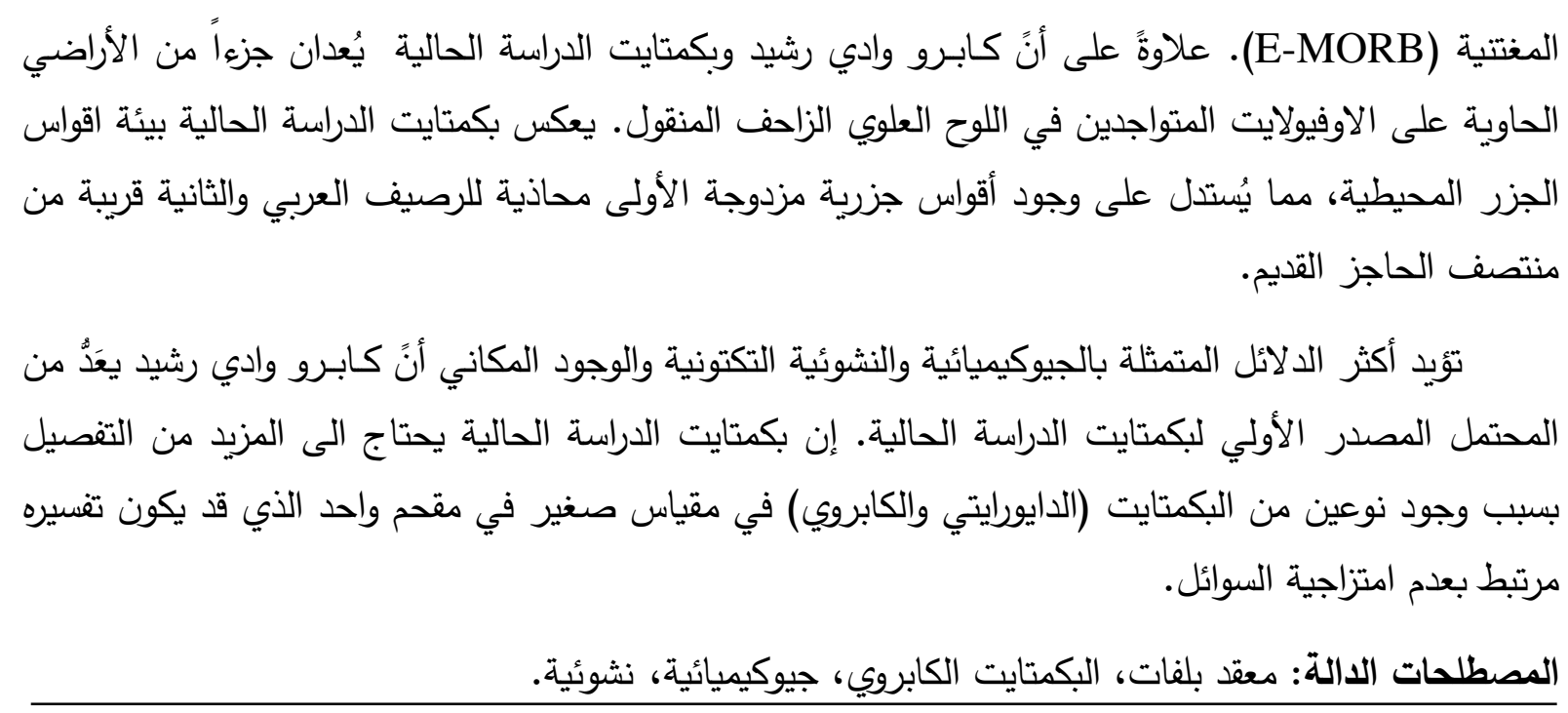

\section{INTRODUCTION}

The pegmatite dikes and associated plutonic rocks stand as a part of the igneous complexes associated with the Bulfat complex, located in the Zagros Suture Zone (ZSZ), NE Iraq (Jassim et al.,1982a) (Fig. 1). ZSZ occupies an area about $5000 \mathrm{~km} 2$ along IraqIran-Turkey borders and within the second unit of the Penjween-Walash Subzone (Buday and Jassim, 1987) (Fig. 1). The Bulfat complex is a part of the ophiolite-bearing terranes that are allochthonous sheets and the complex represents the upper allochthon of the Albian-Cenomenian (Aswad and Elias, 1988; Aswad, 1999), while the WalashNaopurdan sequence represents the lower allochthon of the Palaeogene (Aswad et al., 2011). Allochthonous sheets are located over the autochthonous deposits represented by the sediments of the Arabian shelf and Tertiary sedimentary rocks (Aswad, 1999) (Fig. $1)$.

The Iraqi Bulfat complex (100 $\mathrm{km}^{2}$ in extents in Iraq) outcrops in the mountain of Bulfat near Qala Diza. It comprises a volcano-sedimentary unit as the Gimo and Sirginil groups, these groups were originally referred to the Bulfat group (Jassim et al., 1982a) (Fig. 1). The Gimo group at Bulfat comprises regionally metamorphosed basalt, diabase, andesite, acidic volcanic, tuffs, calcareous, and argillaceous sediments (Jassim et al., 1982b), as a result of the igneous intrusive, aerosols of hornfels and marble were formed that overprinted the regional metamorphic rocks (Jassim et al., 2006a). Whereas the Sirginil group is located in the northern part of the Bulfat complex, this group consists of pelitic and arenaceous rocks with volcanic flows that have undergone a regional and contact metamorphism (Buday and Suk, 1978), forming the upper part of the Bulfat group (Jassim et al., 2006b) (Fig. 1).

The Bulfat complex is generally composed of plutonic rocks (basic, ultrabasic, intermediate, and acidic-granite), these rocks are mainly composed of gabbro-diorite intrusions and accompanied by syenite and nepheline syenite resulting from late-stage magmatic differentiation (Jassim et al., 2006a), forming many rocks intruded during an early Tertiary (Paleocene-Eocene) (Jassim et al., 2006a). The complex is intruded by minor intrusions and pegmatites (Jassim et al., 2006a). Field investigations of the accessible areas at Darishmana appear to reveal that these pegmatite bodies have 
intruded the Albian-Cenomenian metasedimentary sequences (Gimo-Qandil formation) (Aswad and Elias, 1988; Aswad, 1999), which experienced medium-grade regional metamorphism, as overprinted by a high-grade contact metamorphism during Paleogene (Jassim et al., 1982a). Peralkaline magma is produced from the assimilation of the calcareous and pelitic host rocks, these results in the production of pegmatites and nepheline syenite (Buda, 1993). The pegmatites are course-grained dikes cutting both the intrusive and surrounding rocks (Jassim et al., 2006a).

The basic intrusions in the Bulfat group have caused contact metamorphism of the surrounding country rocks (Jassim et al., 2006a). The pyroxene-hornblende gabbros are mostly developed in the northeastern part of the complex, forming the high ground of the Bulfat range along Iraqi-Iranian border, and form a large part of the complex (Jassim et al., 2006a) (Fig. 1), while the olivine gabbro rocks are spread in the form of rock bodies containing varying amounts of olivine (Jassim et al., 2006a).

The complex near the village of Pauza (Shaban valley) contains ultramafic rocks represented by peridotite affected by the serpentinization process (Fig. 1). The ultramafic rocks can be divided into three occurrences (Buday and Jassim, 1987): serpentinites, pyroxenites, and Pauza ultramafic body which form $4 \%$ of the Bulfat igneous complex, representing the major ultramafic occurrence and exhibiting tectonic emplacement features, tectonic breccia along its western contact.

The study area is located in the northeast of Iraq, specifically $74 \mathrm{~km}$ to northeast of Sulaimaniya city. It is located about $13.5 \mathrm{Km}$ to east of Qala Diza subdistric and approximately $4 \mathrm{Km}$ of Darishmana village. The study area extends between longitudes

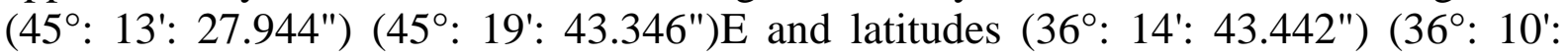
$28.447 ") \mathrm{N}$ close to the Iranian border. Geologically, the study area is located within Bulfat complex of ZSZ, specifically in the northwestern part of this zone and within the second unit of the Penjween-Walash Subzone (Buday and Jassim, 1987). The rock samples were collected from pegmatite dike located to the northeast of the Darishmana village (Fig. 1), whose thickness is about $5 \mathrm{~m}$. The sampling started from the first sample $\left(36^{\circ}: 11^{\prime}: 23.3^{\prime \prime} \mathrm{N} 45^{\circ}: 17^{\prime}: 6.9^{\prime \prime} \mathrm{E}\right)$ and ended with the last sample $\left(36^{\circ}: 11^{\prime}: 24.2^{\prime \prime} \mathrm{N} 45^{\circ}\right.$ : $\left.17^{\prime}: 24.6^{\prime \prime} \mathrm{E}\right)$ where the elevation from sea level is reached about $1793 \mathrm{~m}$.

This paper focuses on pegmatites in the Bulfat complex, throwing light on the variation in the concentrations of the major, trace, and rare earth elements to clarify the petrogenesis, tectonic setting of pegmatites. 


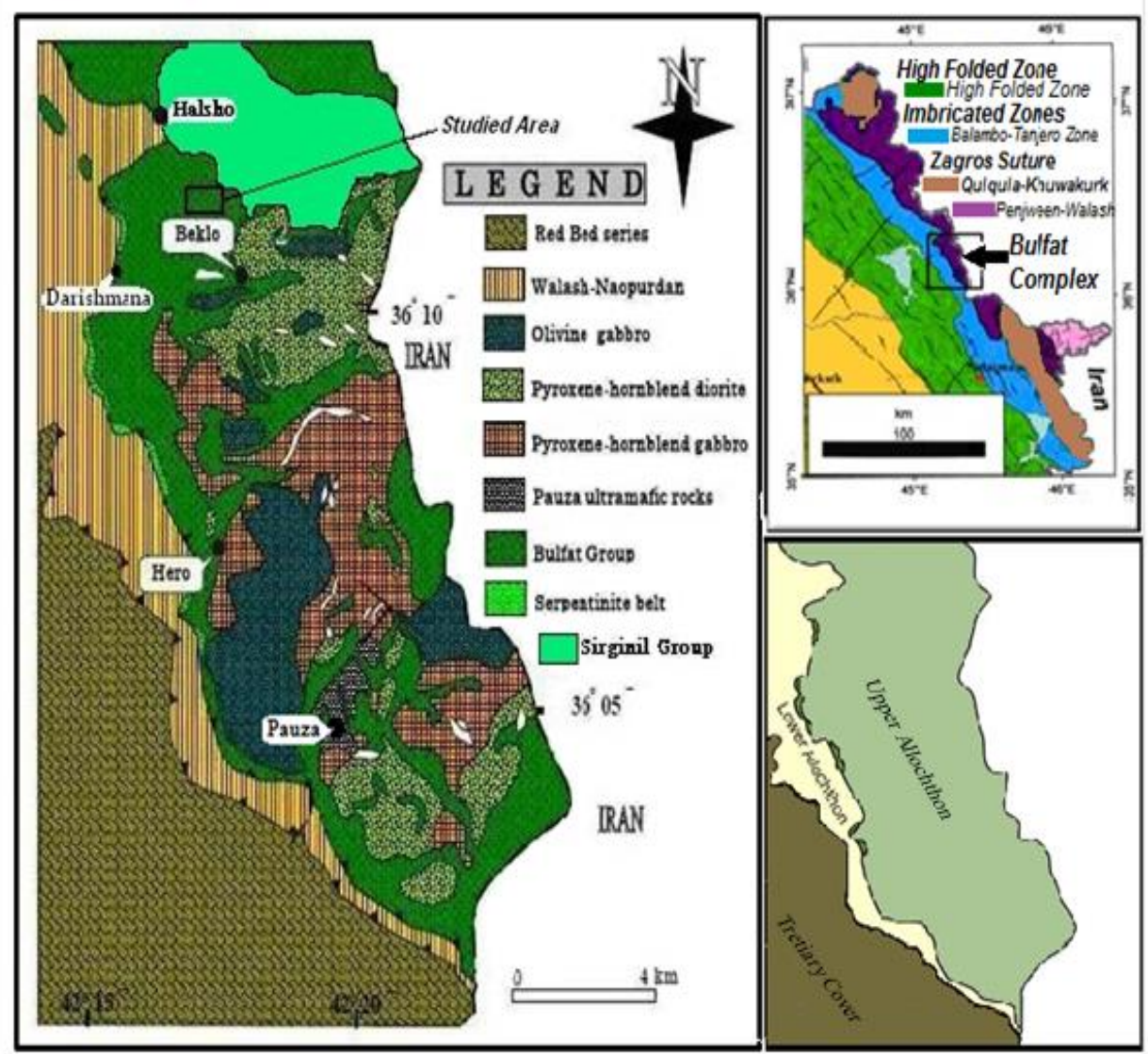

Fig. 1: Geological map of the Bulfat complex (Buday and Jassim, 1987).

\section{METHODOLOGY}

Pegmatite as a very coars-grained intrusive igneous rock, whose interlocking grains are usually larger than $2.5 \mathrm{~cm}$ in size, any attempt to classify these rocks by means of thin section and chemical classification appears to be unscientific. such methods are discovered to be non-representative of bulk minerals, i.e. the classification zone should be markedly larger than the thin section to calculate the mode analysis (Al-Hamed et al., 2019). To overcome this problem, the staining and digital image processing were used (Al-Hamed et al., 2019). The polished slabs were prepared in the Department of Geology, University of Mosul, Iraq, and stained. The Images have taken for the polished and the stained surfaces by a digital camera. By the ENVI software, they were changed into various image styles to calculate and recalculate the color index $\mathrm{M}^{\prime}$, quartz, alkali feldspar, and plagioclase proportions (Al-Hamed et al., 2019).

Electron microprobe analyses (EMPA) were carried out at 8 spots to determine the anorthitic component (An mol. \%) in D7 B and D7 samples utilizing a fully automated, CAMECA SX50 Electron Microprobe at Utah University, USA, fitted with 4 wavelength-dispersive spectrometers, accelerating voltage $15 \mathrm{KeV}$, beam current $30 \mathrm{nA}$, and spot size $10 \mu \mathrm{m}$.

Major, trace, and rare earth elements analysis of fourteen samples were determined by Perkin Elmer Sciex-Elan 6000 (ICP-MS) with a 4-acid digestion at ACME Analytical Laboratories in Canada (Table 1). 
Table 1: Bulk whole-rock chemical analysis of pegmatites.

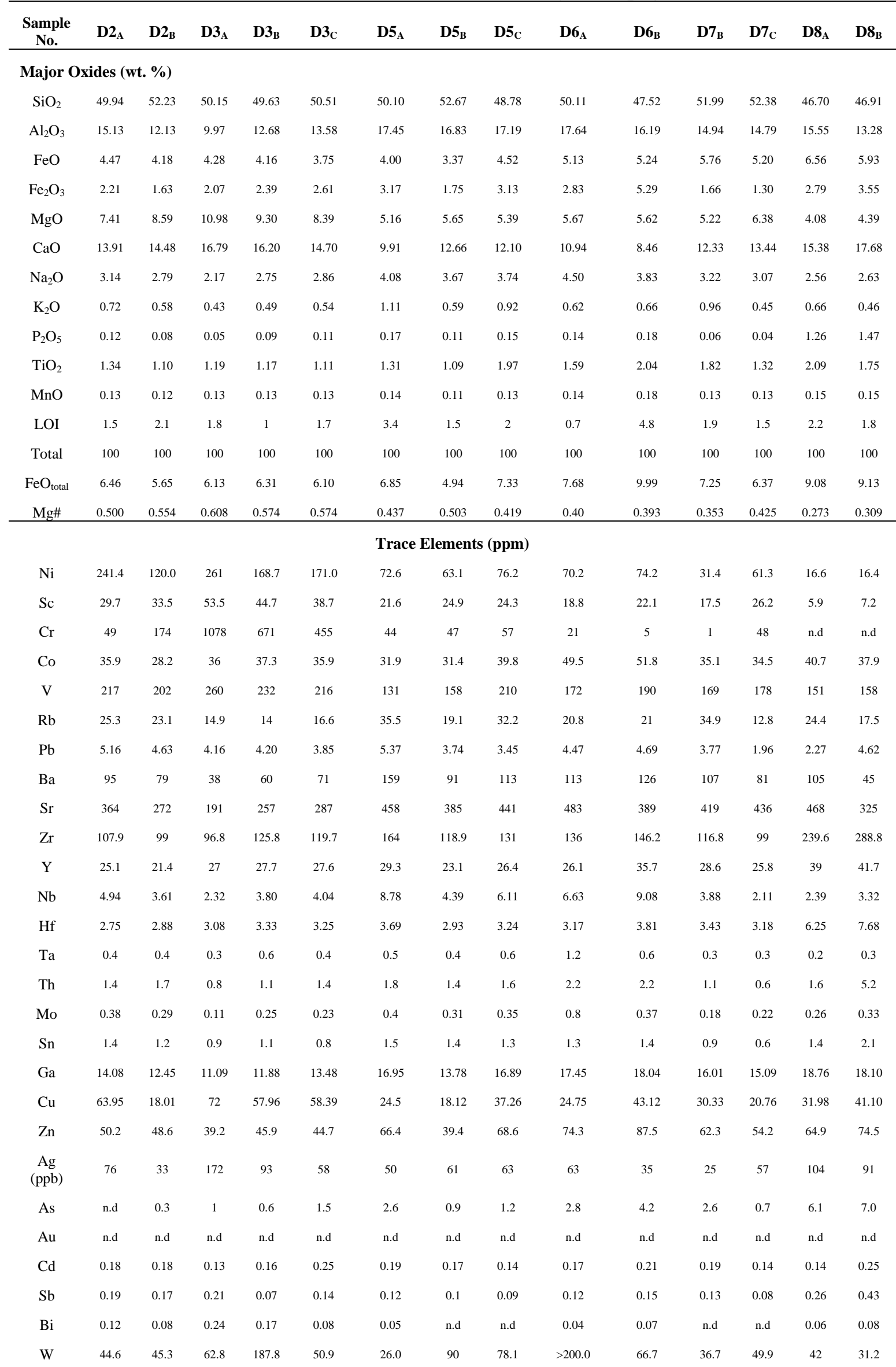




\begin{tabular}{|c|c|c|c|c|c|c|c|c|c|c|c|c|c|c|}
\hline $\mathrm{Be}$ & 1 & n.d & n.d & n.d & n.d & n.d & 1 & n.d & 2 & 1 & n.d & n.d & n.d & n.d \\
\hline $\mathrm{S}$ & n.d & n.d & n.d & n.d & n.d & n.d & n.d & n.d & 900 & n.d & n.d & n.d & n.d & n.d \\
\hline $\mathrm{Li}$ & 25.2 & 33.8 & 24.6 & 21.2 & 24.8 & 43.5 & 12.7 & 18.4 & 10.3 & 14.8 & 17.7 & 15.6 & 29.7 & 31.2 \\
\hline Cs & 1.8 & 0.4 & 0.4 & 0.5 & 1 & 5.1 & 1.2 & 1.2 & 1.0 & 0.7 & 0.3 & 0.7 & 0.9 & 0.2 \\
\hline $\mathrm{U}$ & 0.4 & 0.5 & 0.2 & 0.3 & 0.4 & 0.5 & 0.3 & 0.5 & 0.6 & 0.4 & 0.3 & 0.2 & 0.4 & 1 \\
\hline
\end{tabular}

\begin{tabular}{|c|c|c|c|c|c|c|c|c|c|c|c|c|c|c|}
\hline \multicolumn{15}{|c|}{ Rare Earth Elements (ppm) } \\
\hline $\mathrm{La}$ & 8.3 & 7.2 & 5.4 & 7.7 & 8.1 & 13.1 & 8.5 & 10 & 10.4 & 13.5 & 9 & 6.3 & 19.6 & 23 \\
\hline $\mathrm{Ce}$ & 19.26 & 16.24 & 15.02 & 19.25 & 18.75 & 29.18 & 19.77 & 22.62 & 24.25 & 34.41 & 21.57 & 16.03 & 49.28 & 53.05 \\
\hline $\operatorname{Pr}$ & 2.7 & 2.4 & 2.6 & 3 & 3.1 & 4 & 2.8 & 3.2 & 3 & 5.2 & 3.5 & 2.6 & 7.1 & 7.6 \\
\hline $\mathrm{Nd}$ & 12.1 & 10.3 & 11.7 & 13.7 & 14.2 & 16.1 & 13.8 & 14.8 & 15.1 & 21.2 & 14.6 & 14.1 & 33.4 & 33.4 \\
\hline $\mathrm{Sm}$ & 4.1 & 3.2 & 4.1 & 4.3 & 3.5 & 4.6 & 3.3 & 4.2 & 3.3 & 5.7 & 4.6 & 3 & 7.2 & 7.8 \\
\hline $\mathrm{Eu}$ & 1 & 1.1 & 1.2 & 1.2 & 1 & 1.4 & 1.2 & 1.5 & 1.4 & 1.6 & 1.6 & 1.5 & 2.1 & 1.9 \\
\hline $\mathrm{Gd}$ & 3.7 & 3.9 & 5 & 4.6 & 4.7 & 4.5 & 3.4 & 5 & 4.1 & 5.2 & 4.8 & 4.1 & 8 & 7.3 \\
\hline $\mathrm{Tb}$ & 0.6 & 0.6 & 0.7 & 0.8 & 0.8 & 0.8 & 0.6 & 0.8 & 0.8 & 0.9 & 0.9 & 0.8 & 1.1 & 1.3 \\
\hline Dy & 5 & 4.2 & 5.3 & 6.1 & 4.9 & 4.4 & 4.1 & 5.5 & 4.7 & 6.5 & 5.4 & 4.8 & 7.7 & 7.2 \\
\hline Ho & 1 & 0.9 & 1 & 1 & 0.9 & 1.1 & 0.9 & 1.1 & 1.1 & 1.4 & 1.1 & 1 & 1.5 & 1.7 \\
\hline $\mathrm{Er}$ & 2.4 & 2.7 & 2.7 & 3.3 & 3.4 & 3.0 & 2.4 & 2.7 & 3 & 3.7 & 3 & 3.1 & 3.6 & 3.8 \\
\hline $\mathrm{Tm}$ & 0.5 & 0.3 & 0.4 & 0.4 & 0.5 & 0.5 & 0.4 & 0.4 & 0.4 & 0.5 & 0.5 & 0.4 & 0.6 & 0.6 \\
\hline $\mathrm{Yb}$ & 2.7 & 2 & 2.9 & 2.4 & 2.9 & 2.8 & 2.6 & 2.9 & 2.4 & 4 & 2.6 & 2.3 & 3.7 & 4.5 \\
\hline $\mathrm{Lu}$ & 0.4 & 0.3 & 0.3 & 0.5 & 0.4 & 0.5 & 0.4 & 0.4 & 0.4 & 0.5 & 0.3 & 0.4 & 0.6 & 0.6 \\
\hline $\begin{array}{l}\text { Rock } \\
\text { Name }\end{array}$ & Gabbro & Gabbro & Gabbro & Gabbro & Gabbro & Gabbro & Gabbro & Gabbro & Gabbro & Gabbro & $\begin{array}{l}\text { Melano } \\
\text {-diorite }\end{array}$ & $\begin{array}{l}\text { Melano } \\
\text {-diorite }\end{array}$ & Gabbro & Gabbro \\
\hline
\end{tabular}

$\mathrm{FeO}_{\text {total }}=$ Total $\mathrm{Fe}$ as $\mathrm{FeO}$

$\mathrm{Mg} \#=\left[\mathrm{Mg} /\left(\mathrm{Mg}+\mathrm{Fe}^{+2}\right)\right] \times 100$

n.d $=$ not detected

\section{RESULTS}

Based on the staining and digital image processing that provided by Al-Hamed et al (2019), the classification of the studied pegmatites was melano-diorite and gabbro (Table 2). The extinction angle of plagioclase was calculated to find out An mol. \% in the plagioclase using the Michale Levy method to differentiate between melano-diorite and gabbro (Table 3). The plagioclase composition was andesine in D7 ${ }_{\mathrm{B}}$ and D7C samples and $\mathrm{M}^{\prime}>50 \%$, indicating that these samples are melanocratic. Moreover, electron microprobe analyses (EMPA) of plagioclase in D7 $\mathrm{B}$ and D7 $\mathrm{C}$ samples are shown in Table 4. The anorthitic component (An mol. \%) ranges between oligoclase $\left(\mathrm{An}_{18.00^{-}}\right.$ $\left.\mathrm{An}_{28.23}\right)$ and andesine $\left(\mathrm{An}_{32.53}-\mathrm{An}_{33.62}\right)$ for $\mathrm{D} 7_{\mathrm{B}}$ and $\mathrm{D} 7_{\mathrm{C}}$ samples respectively. The difference in plagioclase compositions in the $\mathrm{D} 7_{\mathrm{B}}$ and $\mathrm{D} 7_{\mathrm{C}}$ samples from the other studied samples may be related to the magmatic fractionation, revealing more sodic plagioclase with progressive magma differentiation (Shawna et al., 2003). 
Table 2: Classification and nomenclature of pegmatites, specifying recalculation of the color

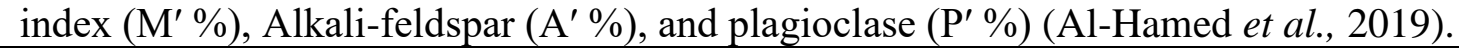

\begin{tabular}{|c|c|c|c|c|c|c|}
\hline \multirow{2}{*}{ Samples } & \multirow{2}{*}{$\mathbf{M}^{\prime} \%$} & \multirow{2}{*}{$\begin{array}{c}\text { Alkali } \\
\text { Feldspar \% }\end{array}$} & \multirow{2}{*}{$\begin{array}{c}\text { Plagioclase } \\
\%\end{array}$} & \multicolumn{2}{|c|}{ Total Feldspars $=100$} & \multirow{2}{*}{ Name of Rock } \\
\hline & & & & $\mathbf{A}^{\prime} \%$ & $\mathbf{P}^{\prime} \%$ & \\
\hline $\mathbf{D 2} \mathbf{A}_{\mathrm{A}}$ & 52 & 0 & 48 & 0 & 100 & Gabbroic pegmatite \\
\hline D2 ${ }_{B}$ & 60 & 0 & 40 & 0 & 100 & Gabbroic pegmatite \\
\hline $\mathbf{D 3}_{\mathrm{A}}$ & 57 & 0.6 & 42.4 & 1.5 & 98.5 & Gabbroic pegmatite \\
\hline $\mathbf{D 3}_{\mathbf{B}}$ & 58 & 0,5 & 41.5 & 1.2 & 98.8 & Gabbroic pegmatite \\
\hline $\mathbf{D 3}_{\mathrm{C}}$ & 56 & 0.6 & 43.4 & 1,4 & 98.6 & Gabbroic pegmatite \\
\hline $\mathbf{D 5}_{\mathrm{A}}$ & 51 & 4.1 & 44.9 & 8.4 & 91.6 & Gabbroic pegmatite \\
\hline D5 $_{\mathbf{B}}$ & 50 & 3.8 & 46.2 & 7.5 & 92.5 & Gabbroic pegmatite \\
\hline D5C $_{C}$ & 51 & 4.4 & 44.6 & 9 & 91 & Gabbroic pegmatite \\
\hline D6 $_{A}$ & 61.5 & 0 & 38.5 & 0 & 100 & Gabbroic pegmatite \\
\hline D6в & 63.7 & 0.2 & 36.1 & 0.6 & 99.4 & Gabbroic pegmatite \\
\hline D7 & 61.8 & 0 & 38.2 & 0 & 100 & Melano-dioritic pegmatite \\
\hline $\mathbf{D 7}_{\mathrm{C}}$ & 51 & 0 & 49 & 0 & 100 & Melano-dioritic pegmatite \\
\hline D8 & 53 & 0 & 47 & 0 & 100 & Gabbroic pegmatite \\
\hline D8 $_{\mathbf{B}}$ & 62.5 & 0.6 & 36.9 & 1.7 & 98.3 & Gabbroic pegmatite \\
\hline \multicolumn{7}{|c|}{$\mathrm{M}^{\prime} \%=100 \times[\mathrm{M} /(\mathrm{M}+\mathrm{A}+\mathrm{P})]$} \\
\hline \multicolumn{7}{|c|}{$\mathrm{A}^{\prime} \%=100 \times[\mathrm{A} /(\mathrm{A}+\mathrm{P})$} \\
\hline \multicolumn{7}{|c|}{$\mathrm{P}^{\prime} \%=100 \times[\mathrm{P} /(\mathrm{A}+\mathrm{P})]$} \\
\hline $\mathrm{A}^{\prime}+\mathrm{P}^{\prime}=$ & & & & & & \\
\hline
\end{tabular}

Table 3: The composition of plagioclase in the samples of pegmatites.

\begin{tabular}{|c|c|c|c|c|}
\hline Samples & Extinction Angle & An mol. \% & Plagioclase & Rock types \\
\hline $\mathbf{D} 2_{\mathrm{A}}$ & $29-31$ & $52-56$ & Labradorite & Gabbro \\
\hline D2 ${ }_{B}$ & $33-36$ & $59-64$ & Labradorite & Gabbro \\
\hline $\mathbf{D 3}_{\mathrm{A}}$ & $30-33$ & $54-59$ & Labradorite & Gabbro \\
\hline D3 $_{B}$ & $29-32$ & $52-57$ & Labradorite & Gabbro \\
\hline D3C $_{C}$ & $30-34$ & $54-60$ & Labradorite & Gabbro \\
\hline D5 $_{A}$ & $32-33$ & $57-59$ & Labradorite & Gabbro \\
\hline D5 $_{B}$ & $30-31$ & $54-56$ & Labradorite & Gabbro \\
\hline $\mathbf{D 5}_{\mathrm{C}}$ & $29-31$ & $52-56$ & Labradorite & Gabbro \\
\hline D6 $_{A}$ & $30-33$ & $54-59$ & Labradorite & Gabbro \\
\hline D6в & $30-32$ & $54-57$ & Labradorite & Gabbro \\
\hline D7 & $20-22$ & $38-41$ & Andesine & Diorite \\
\hline D7 $C$ & $21-26$ & $40-47$ & Andesine & Diorite \\
\hline D8 $_{A}$ & $32-34$ & $57-60$ & Labradorite & Gabbro \\
\hline D8 $_{B}$ & $30-33$ & $54-59$ & Labradorite & Gabbro \\
\hline
\end{tabular}


72 Geochemistry and Petrogenesis of Dioritic-Gabbroic Pegmatites in the Bulfat ......

Table 4: EMPA of plagioclase feldspar based on 8 oxygens.

\begin{tabular}{|c|c|c|c|c|c|c|c|c|}
\hline Samples & D7 $C-A$ & D7C-A & D7 & D7 & D7 $7_{B}-B$ & D7 & D7 & D7C-A \\
\hline $\mathrm{SiO}_{2}$ & 60.766 & 59.819 & 62.081 & 62.086 & 61.407 & 61.400 & 62.779 & 60.114 \\
\hline $\mathrm{TiO}_{2}$ & 0.000 & 0.000 & 0.000 & 0.000 & 0.044 & 0.000 & 0.004 & 0.024 \\
\hline $\mathrm{Al}_{2} \mathrm{O}_{3}$ & 25.854 & 25.776 & 24.399 & 25.050 & 22.766 & 22.665 & 23.093 & 26.153 \\
\hline $\mathrm{FeO}^{*}$ & 0.034 & 0.048 & 0.019 & 0.018 & 0.015 & 0.074 & 0.061 & 0.016 \\
\hline MnO & 0.000 & 0.030 & 0.016 & 0.000 & 0.000 & 0.000 & 0.021 & 0.037 \\
\hline MgO & 0.000 & 0.000 & 0.021 & 0.006 & 0.000 & 0.001 & 0.000 & 0.000 \\
\hline $\mathrm{CaO}$ & 6.629 & 6.796 & 5.251 & 5.661 & 3.995 & 3.934 & 3.609 & 6.913 \\
\hline $\mathrm{BaO}$ & 0.000 & 0.111 & 0.054 & 0.136 & 0.138 & 0.017 & 0.016 & 0.052 \\
\hline $\mathrm{Na}_{2} \mathrm{O}$ & 7.530 & 7.347 & 8.340 & 7.829 & 8.905 & 8.899 & 8.929 & 7.458 \\
\hline $\mathbf{K}_{2} \mathrm{O}$ & 0.103 & 0.104 & 0.154 & 0.190 & 0.194 & 0.199 & 0.242 & 0.195 \\
\hline Total & 101.277 & 100.623 & 100.982 & 101.498 & 97.990 & 97.813 & 99.430 & 101.498 \\
\hline & & Number & of Ions ca & culated o & 8 oxyger & basis & & \\
\hline $\mathbf{S i}$ & 2.689 & 2.672 & 2.750 & 2.743 & 2.789 & 2.795 & 2.814 & 2.657 \\
\hline $\mathbf{T i}$ & 0.000 & 0.000 & 0.000 & 0.000 & 0.001 & 0.000 & 0.000 & 0.001 \\
\hline Al & 1.348 & 1.357 & 1.274 & 1.305 & 1.219 & 1.216 & 1.220 & 1.362 \\
\hline $\mathrm{Fe}^{+2}$ & 0.001 & 0.002 & 0.001 & 0.001 & 0.001 & 0.003 & 0.002 & 0.001 \\
\hline Mn & 0.000 & 0.001 & 0.001 & 0.000 & 0.000 & 0.000 & 0.001 & 0.001 \\
\hline Mg & 0.000 & 0.000 & 0.001 & 0.000 & 0.000 & 0.000 & 0.000 & 0.000 \\
\hline $\mathbf{C a}$ & 0.314 & 0.325 & 0.249 & 0.268 & 0.194 & 0.192 & 0.173 & 0.327 \\
\hline $\mathbf{B a}$ & 0.000 & 0.002 & 0.001 & 0.002 & 0.002 & 0.000 & 0.000 & 0.001 \\
\hline $\mathbf{N a}$ & 0.646 & 0.636 & 0.716 & 0.671 & 0.784 & 0.785 & 0.776 & 0.639 \\
\hline $\mathbf{K}$ & 0.006 & 0.006 & 0.009 & 0.011 & 0.011 & 0.012 & 0.014 & 0.011 \\
\hline \multicolumn{9}{|c|}{ Molecular Ratio } \\
\hline An & 32.530 & 33.618 & 25.580 & 28.227 & 19.641 & 19.401 & 17.997 & 33.489 \\
\hline $\mathbf{A b}$ & 66.870 & 65.768 & 73.529 & 70.646 & 79.221 & 79.429 & 80.564 & 65.387 \\
\hline Or & 0.599 & 0.614 & 0.892 & 1.127 & 1.137 & 1.169 & 1.439 & 1.124 \\
\hline
\end{tabular}




\section{Geochemistry of Pegmatites:}

In order to clarify the geochemical variation of the major oxides and trace elements, the binary variation diagrams using $\mathrm{MgO}$ and $\mathrm{FeO}_{\text {total }}$ were used against the major oxides and trace elements, because $\mathrm{MgO}$ and $\mathrm{FeO}_{\text {total }}$ are concentrated in the mafic minerals are reflected by the variation in the color index $(\mathrm{M} \%)$ which range between (50-63.7 \%) (Table 2), as well as that $\mathrm{MgO}$ and $\mathrm{FeO}_{\text {total }}$ are increased in these rocks.

\section{Major Oxides:}

Alkalinity Index (AI) refers to that the studied pegmatites are metaluminous (A/NK > 2) (Fig. 2). Generally, the silica range in these pegmatites is from $46.70 \mathrm{wt} . \%$ to 52.67 wt. \% (Table 1), showing a dispersed correlation with $\mathrm{MgO}$ and a negative correlation with $\mathrm{FeO}_{\text {total }}$ (Fig. 3A, B). The silica correlation with $\mathrm{FeO}_{\text {total }}$ reflects the magmatic fractionation of plagioclase, where plagioclase becomes more sodic with progressive magmatic fractionation (Shawna et al., 2003).

$\mathrm{Al}_{2} \mathrm{O}_{3}$ and $\mathrm{Na}_{2} \mathrm{O}$ show two continuous trends with $\mathrm{MgO}$ (Fig. $3 \mathrm{C}, \mathrm{E}$ ), the first reflects an increase in $\mathrm{Al}_{2} \mathrm{O}_{3}$ and $\mathrm{Na}_{2} \mathrm{O}$ with increasing $\mathrm{MgO}$, indicating the start of plagioclase fractionation; whereas the second trend shows a decrease in these oxides with increasing $\mathrm{MgO}$, indicating fractionation of clinopyroxene. $\mathrm{CaO}$ has also two trends with $\mathrm{MgO}$ (Fig. 3G), the first represents an increase in $\mathrm{CaO}$ with decreasing $\mathrm{MgO}$, indicating fractionation of plagioclase and depletion of $\mathrm{Mg}$ in clinopyroxene with stability of Ca content (Sofy, 2003); whereas the second trend shows an increase in $\mathrm{CaO}$ with increasing $\mathrm{MgO}$, reflecting fractionation of clinopyroxene. The correlations of $\mathrm{Al}_{2} \mathrm{O}_{3}, \mathrm{Na}_{2} \mathrm{O}$, and $\mathrm{CaO}$ with $\mathrm{MgO}$ (Fig. 3C, E, and $\mathrm{G}$ ) may reflect liquid immiscibility in the single intrusion. $\mathrm{Al}_{2} \mathrm{O}_{3}, \mathrm{Na}_{2} \mathrm{O}$, and $\mathrm{CaO}$ show a dispersed correlation with $\mathrm{FeO}_{\text {total }}$ (Fig. 3D, F, $\mathrm{H}$ ). $\mathrm{TiO}_{2}$ and $\mathrm{MnO}$ have a dispersed correlation with $\mathrm{MgO}$ and a positive correlation with $\mathrm{FeO}_{\text {total }}$ (Fig. $3 \mathrm{~V}, \mathrm{X}, \mathrm{Y}, \mathrm{Z}$ ), this reflects that these oxides occur in the Fe-phase minerals as pyrrhotite.

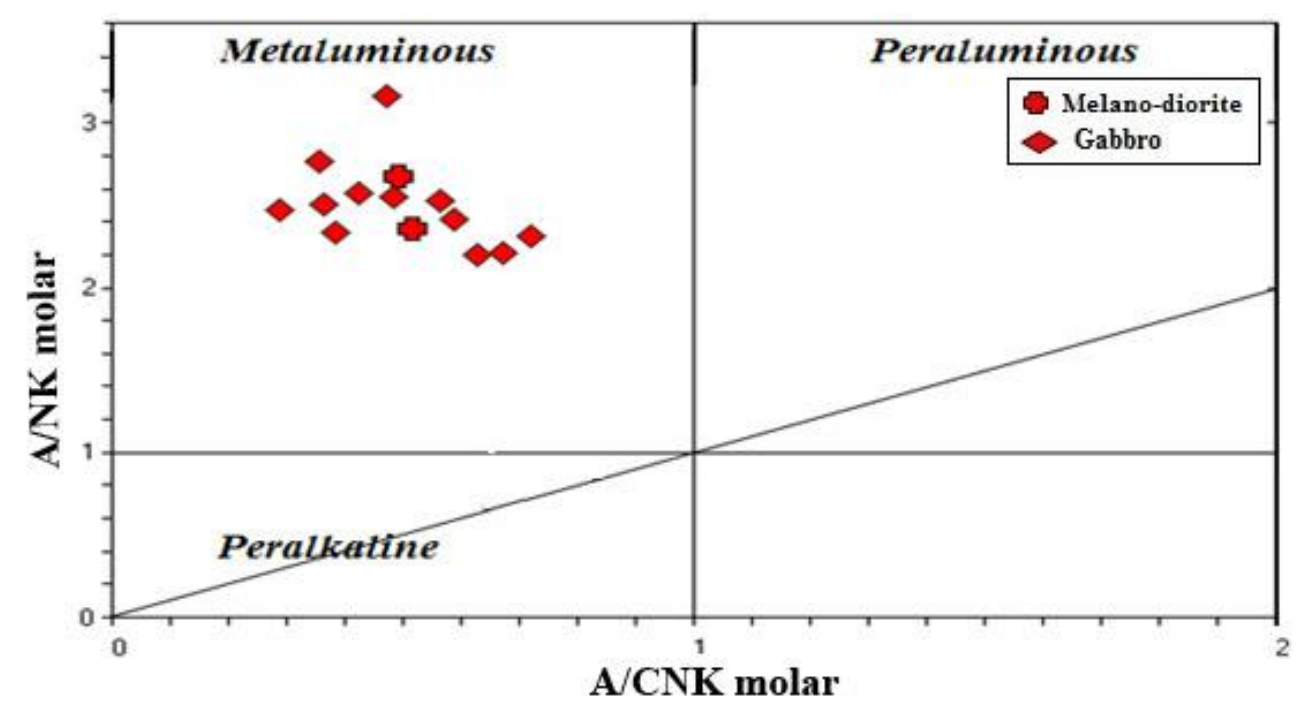

Fig. 2: $\mathrm{A} / \mathrm{NK}\left(\mathrm{Al}_{2} \mathrm{O}_{3} / \mathrm{Na}_{2} \mathrm{O}+\mathrm{K}_{2} \mathrm{O}\right)$ vs. $\mathrm{A} / \mathrm{CNK}\left(\mathrm{Al}_{2} \mathrm{O}_{3} / \mathrm{CaO}+\mathrm{Na}_{2} \mathrm{O}+\mathrm{K}_{2} \mathrm{O}\right)$ plots show field of pegmatites of the Bulfat complex, Iraq, from (Maniar and Piccoli, 1989). 


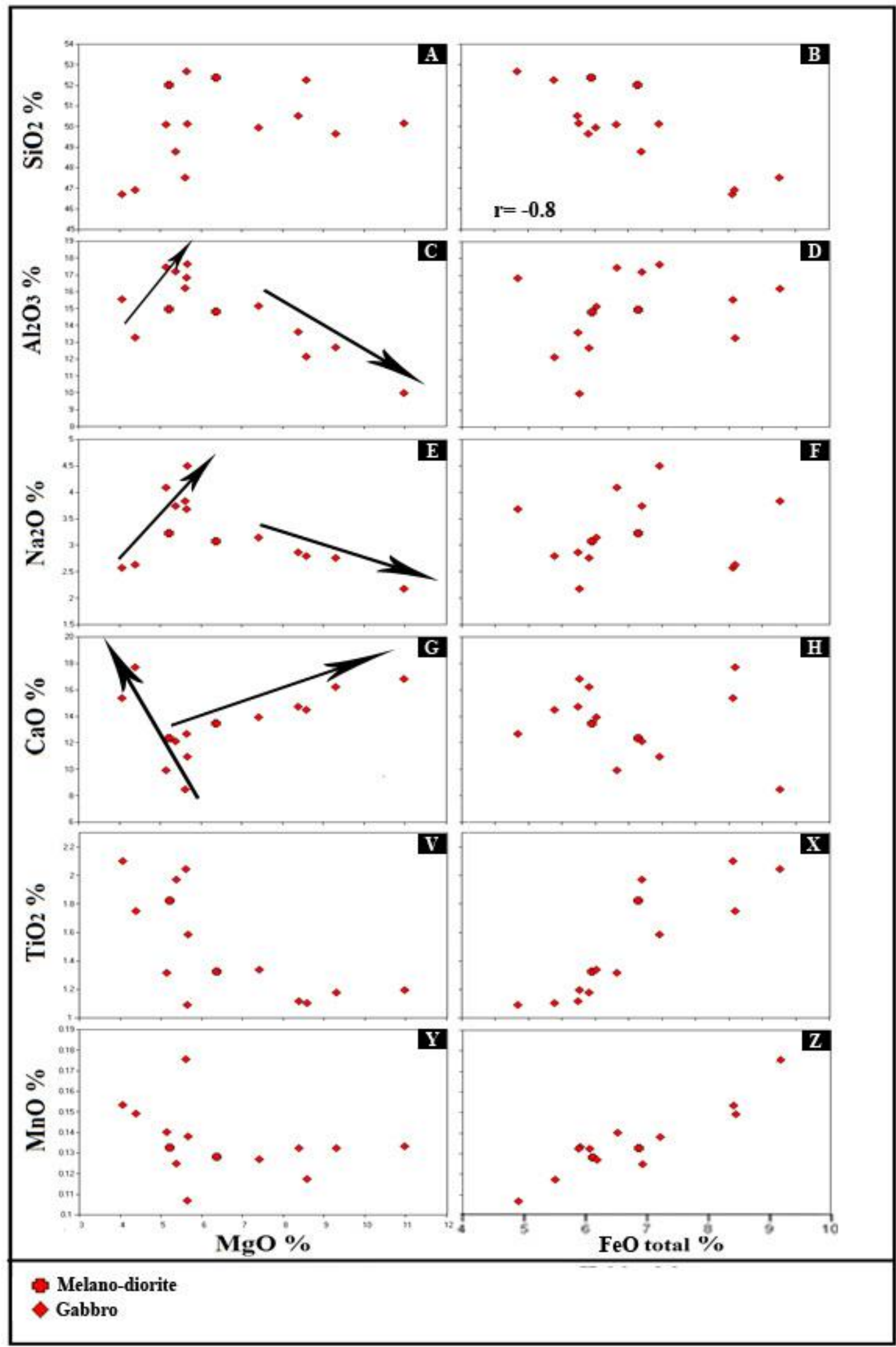

Fig. 3: Variation diagram of $\mathrm{MgO}$ and $\mathrm{FeO}_{\text {total }}$ vs. major oxides of pegmatites in the Bulfat complex. 


\section{Trace Elements:}

$\mathrm{Ni}$ shows a positive correlation with $\mathrm{MgO}\left(\mathrm{r}^{\mathrm{MgO} / \mathrm{Ni}}=0.82\right)$ and a dispersed correlation with $\mathrm{FeO}_{\text {total }}$ (Fig. 4A, B), this reflects that $\mathrm{Ni}^{2+}$ replaces $\mathrm{Mg}^{2+}$ in clinopyroxene (augite) (Rollinson, 1993). Also Sc and V show a dispersed correlation with $\mathrm{FeO}_{\text {total, }}$, indicating the scarcity of their presence in accessory Fe-rich phases (Fig. $4 \mathrm{D}, \mathrm{F})$. Whereas, Sc and $\mathrm{V}$ have a strong positive correlation with $\mathrm{MgO}\left(\mathrm{r}^{\mathrm{MgO} / \mathrm{Sc}}=0.91\right.$ and $\mathrm{r}^{\mathrm{MgO} / \mathrm{V}}=0.83$ ) (Fig. $4 \mathrm{C}, \mathrm{E}$ ) which confirms their presence in one phase (augite) (Mason and Moore, 1982; Wodepohl, 1978). Co has a dispersed relationship with $\mathrm{MgO}$ and is positively associated with $\mathrm{FeO}_{\text {total }}\left(\mathrm{r}^{\mathrm{FeO} \text { total/Co }}=0.68\right)(\mathrm{Fig} .4 \mathrm{G}, \mathrm{H})$, this reflects that Co increases in accessory Fe-rich phases, especially ferric, where Co has a positive correlation with ferric $(r=0.7)$.

LILEs ( $\mathrm{Rb}, \mathrm{Ba}, \mathrm{Sr})$ show a negative correlation with $\mathrm{MgO}$ and a dispersed correlation with $\mathrm{FeO}_{\text {total }}$ (Fig. 5A, B, C, D, E, F), indicating that $\mathrm{Rb}, \mathrm{Ba}$, and $\mathrm{Sr}$ are associated with felsic minerals (Mason and Moore, 1982) since the felsic minerals in these rocks are dominated by plagioclase, so this mineral is the host of $\mathrm{Rb}, \mathrm{Ba}$, and $\mathrm{Sr}$. $\mathrm{Cs}$ and $\mathrm{Li}$ do not show any clear correlation with $\mathrm{MgO}$ and $\mathrm{FeO}_{\text {total }}$ (Fig. 5G, H, V, X), $\mathrm{Cs}$ is highly incompatible due to the very large ionic radius but is associated with feldspars and micas (Linnen et al., 2012), while Li has a much smaller ionic radius than that of other alkali metals and is associated with amphiboles and micas by coupled substitution reactions (London, 2005a). Generally, the melts crystallize under equilibrium conditions, whereas pegmatitic melt crystallizes under super-cooled conditions far from the equilibrium (Chakoumakos and Lumpkin, 1990; Morgan and London, 1999; Webber et al., 1999). Therefore, the difference occurs in the fractionation and behaviour of LILEs from what is expected in other melts (London, 2005b).

HFSEs have a medium negative correlation with $\mathrm{MgO}$ and a positive with $\mathrm{FeO}_{\text {total }}$ (Fig. 6A, B, C, D, E, F), indicating their presence in Fe-rich minerals. Zr, Y, and Hf elements show a strong positive correlation with each other (Fig. 7), reflecting their common existence where be formed from a single source of mafic magma by fractional crystallization (Wilson, 1989). $\mathrm{Nb}$ and Ta have an unclear correlation with $\mathrm{MgO}$ and $\mathrm{FeO}_{\text {total }}$ (Fig. 6G, H, V, X). Th and $\mathrm{U}$ show a dispersed correlation with $\mathrm{MgO}$ and $\mathrm{FeO}_{\text {total }}$ (Fig. 8), indicating that they are associated with accessory minerals.

Chalcophile elements ( $\mathrm{Sn}, \mathrm{Zn}, \mathrm{Cu}$ ) show divergent correlations with $\mathrm{MgO}$ and $\mathrm{FeO}_{\text {total }}$ (Fig. 8). Sn and $\mathrm{Cu}$ show a dispersed correlation with $\mathrm{MgO}$ and $\mathrm{FeO}_{\text {total }}$ (Fig. 9A, B, E, F). Zn exhibits a negative correlation with $\mathrm{MgO}$ and a strong positive correlation with $\mathrm{FeO}_{\text {total }}(\mathrm{r}=0.9)$ (Fig. 9C, D), this indicates that $\mathrm{Zn}$ entered Fe-rich phases, it replaces ferrous due to the similarity of charge and radius $\left(\mathrm{Zn}^{2+} 0.74 \AA, \mathrm{Fe}^{2+}\right.$ $0.74 \AA)$. 


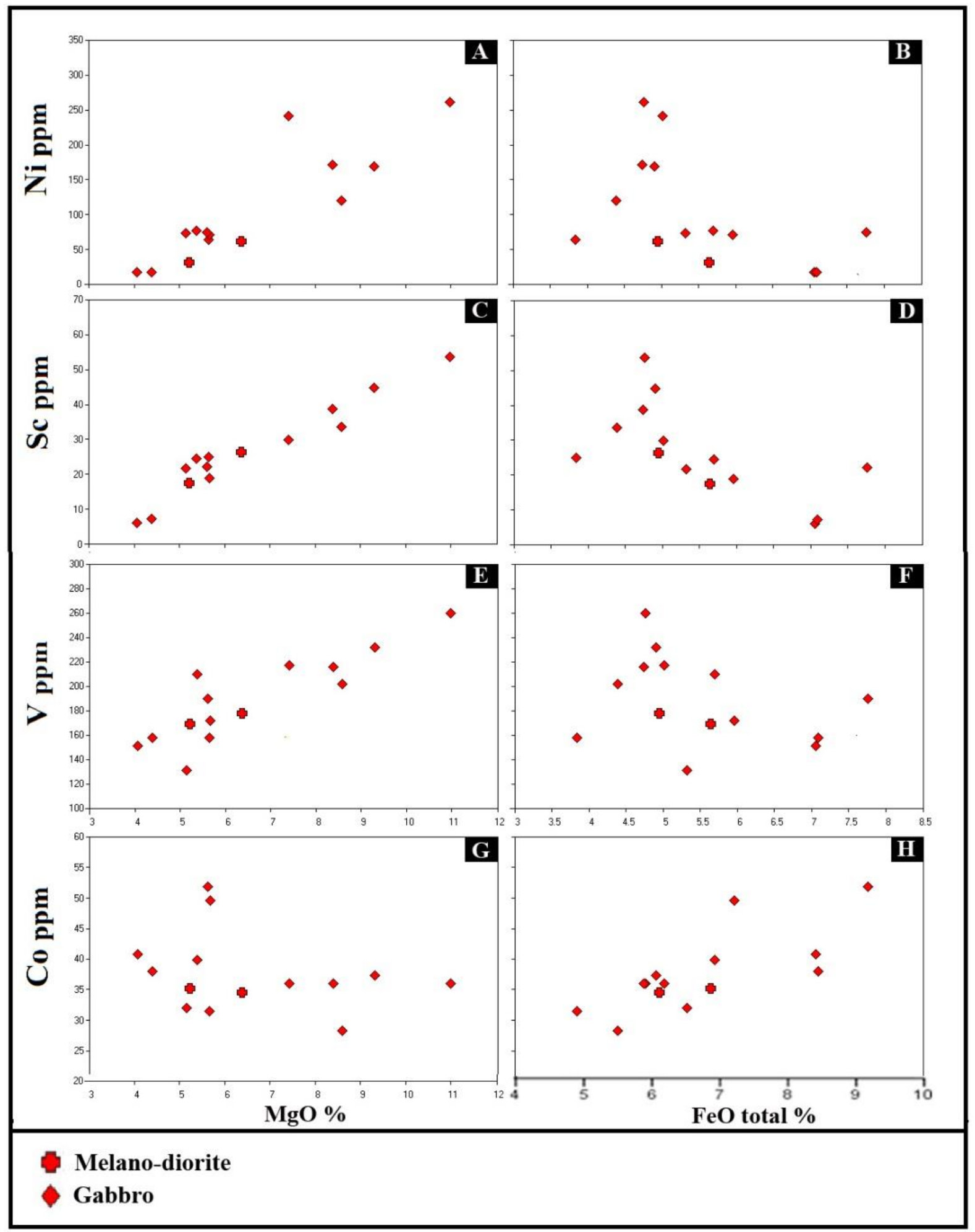

Fig. 4: Variation diagram of $\mathrm{MgO}$ and $\mathrm{FeO}_{\text {total }}$ vs. $\mathrm{Ni}, \mathrm{Sc}, \mathrm{V}$, and $\mathrm{Co}$ of pegmatites in the Bulfat complex. 


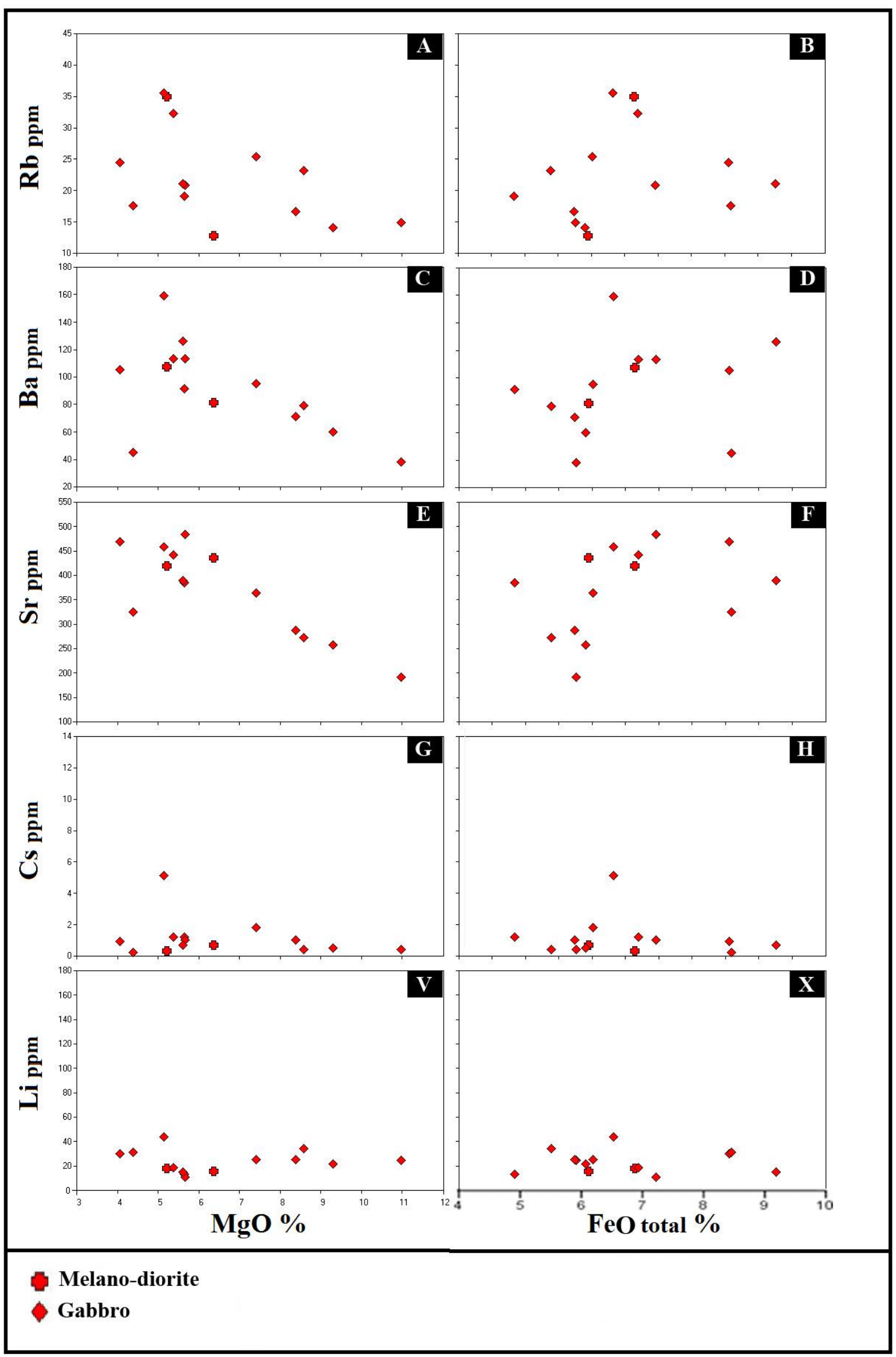

Fig. 5: Variation diagram of $\mathrm{MgO}$ and $\mathrm{FeO}_{\text {total }}$ vs. LILEs of pegmatites in the Bulfat complex. 


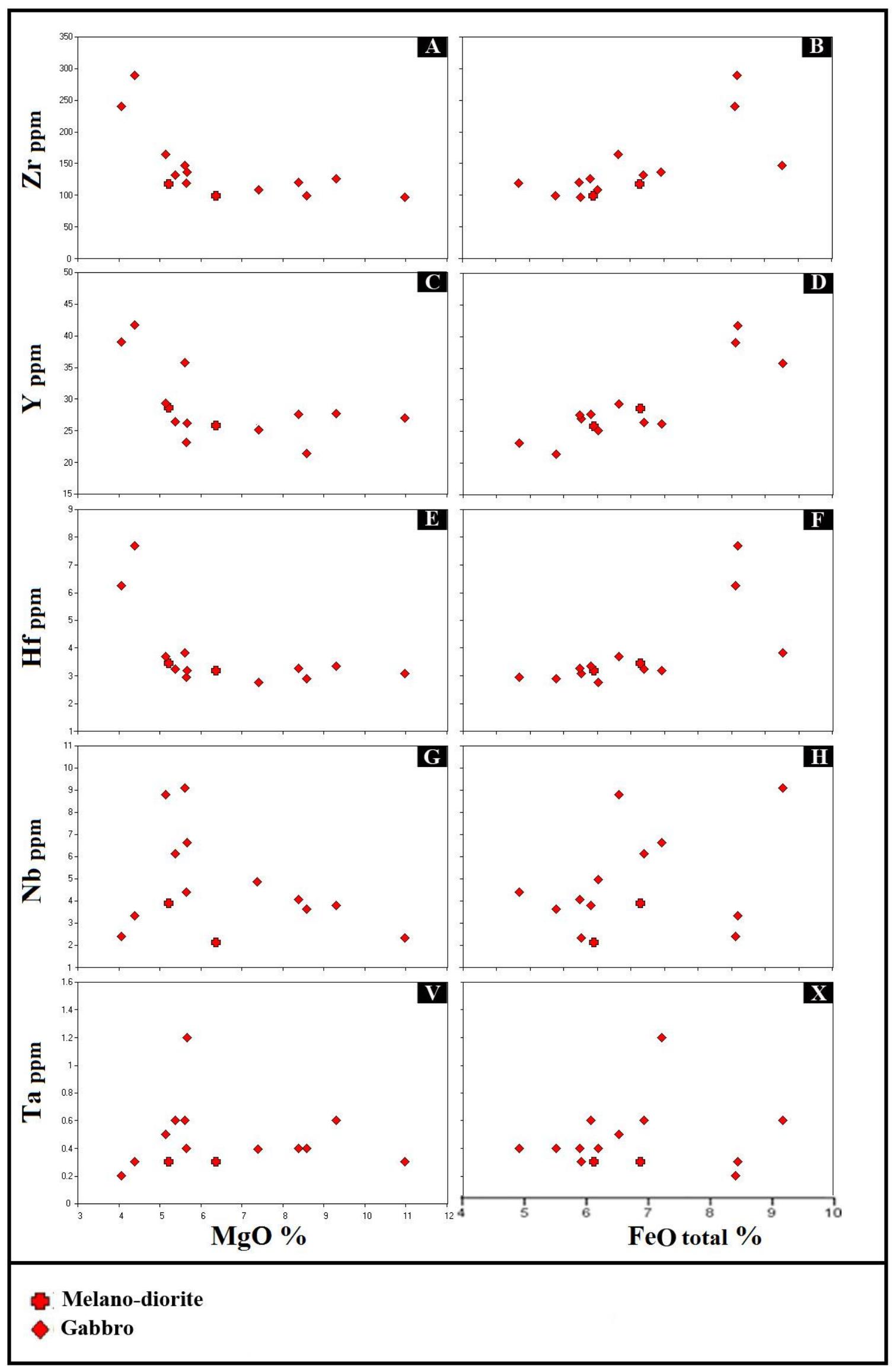

Fig. 6: Variation diagram of $\mathrm{MgO}$ and $\mathrm{FeO}_{\text {total }}$ vs. HFSEs of pegmatites in the Bulfat complex. 


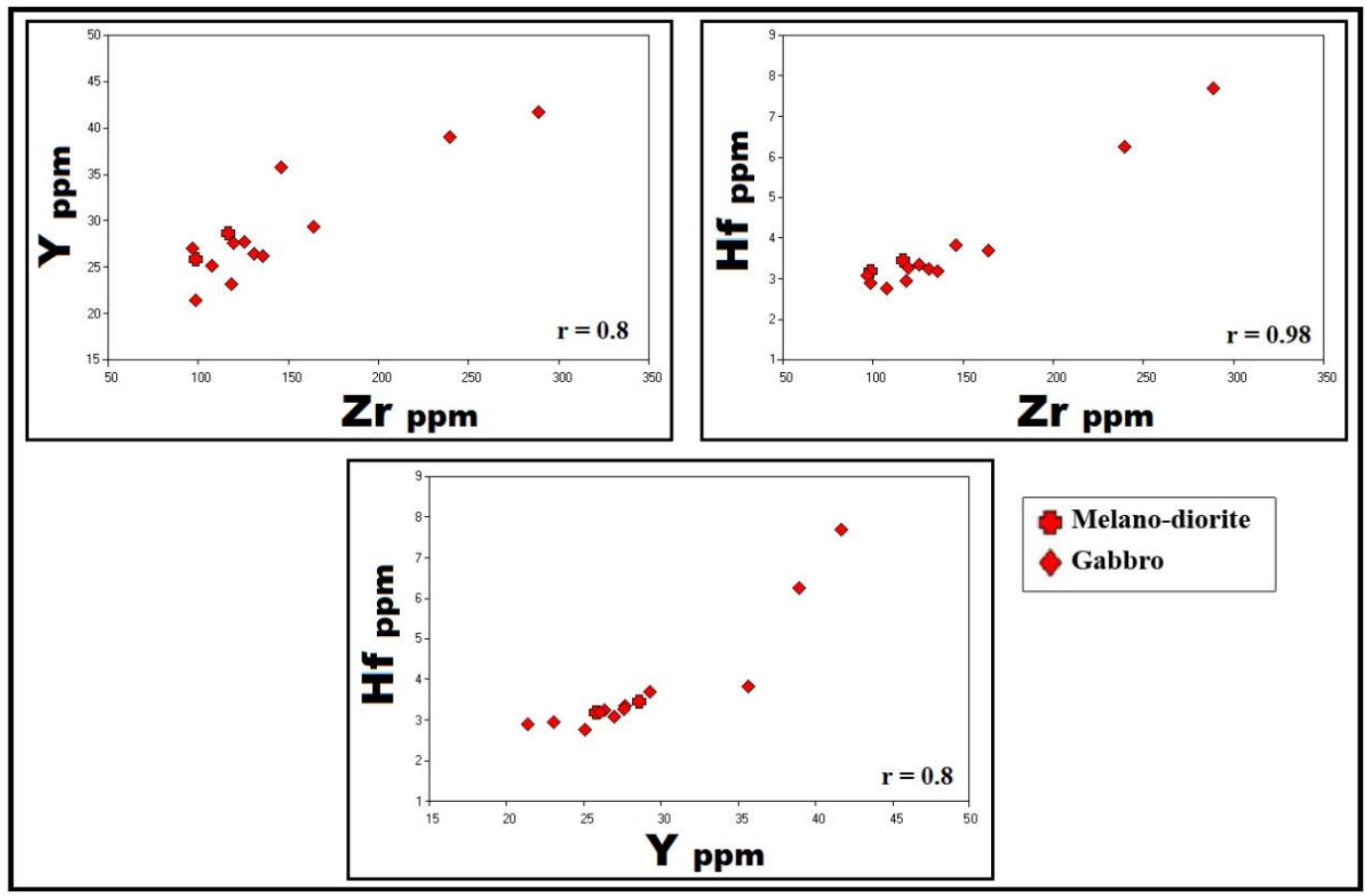

Fig. 7: Variation diagram of Zr vs. Y and Hf; Y vs. Hf of pegmatites in the Bulfat complex.

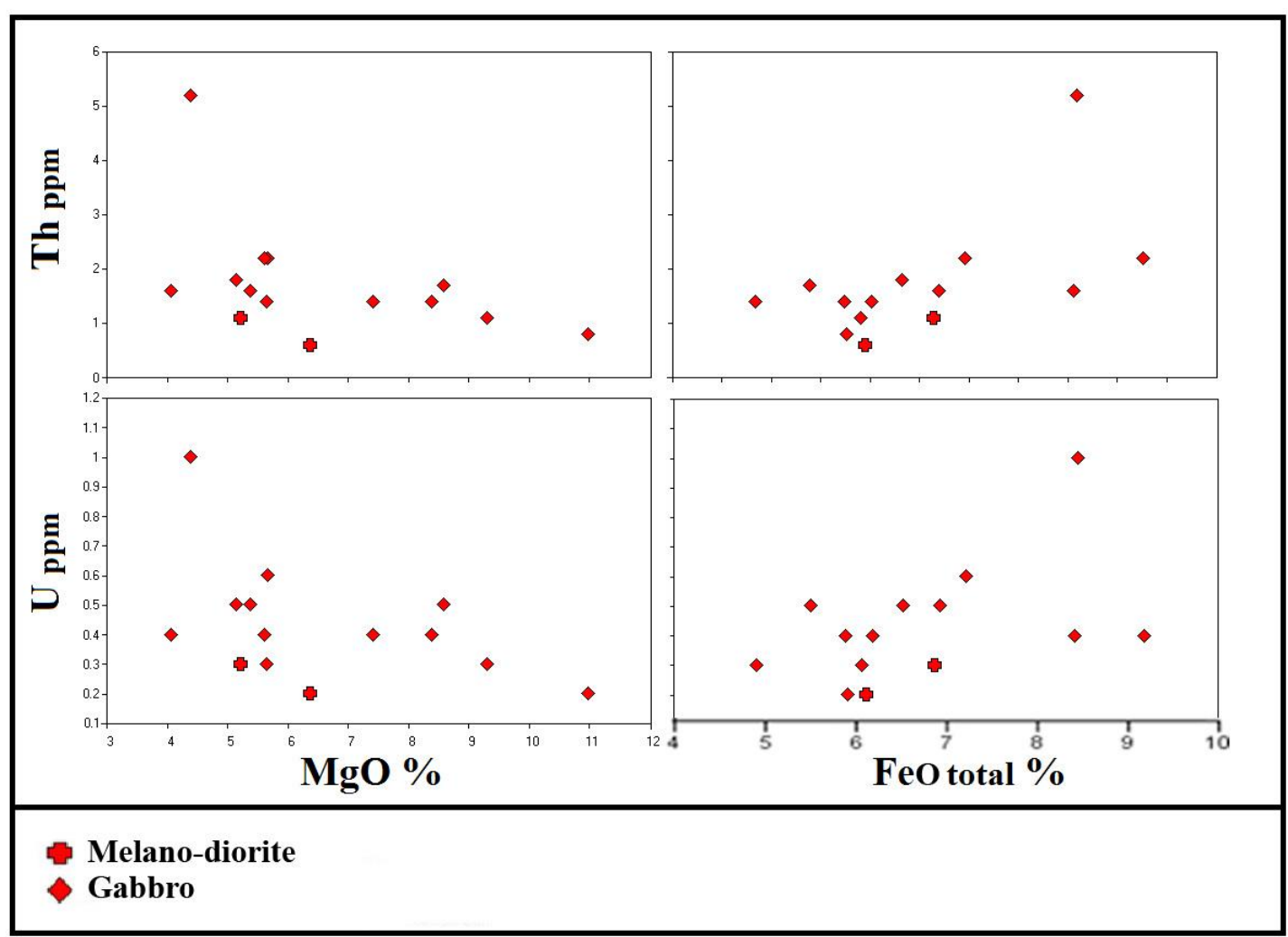

Fig. 8: Variation diagram of $\mathrm{MgO}$ and $\mathrm{FeO}_{\text {total }}$ vs. Th and $\mathrm{U}$ of pegmatites in the Bulfat complex. 


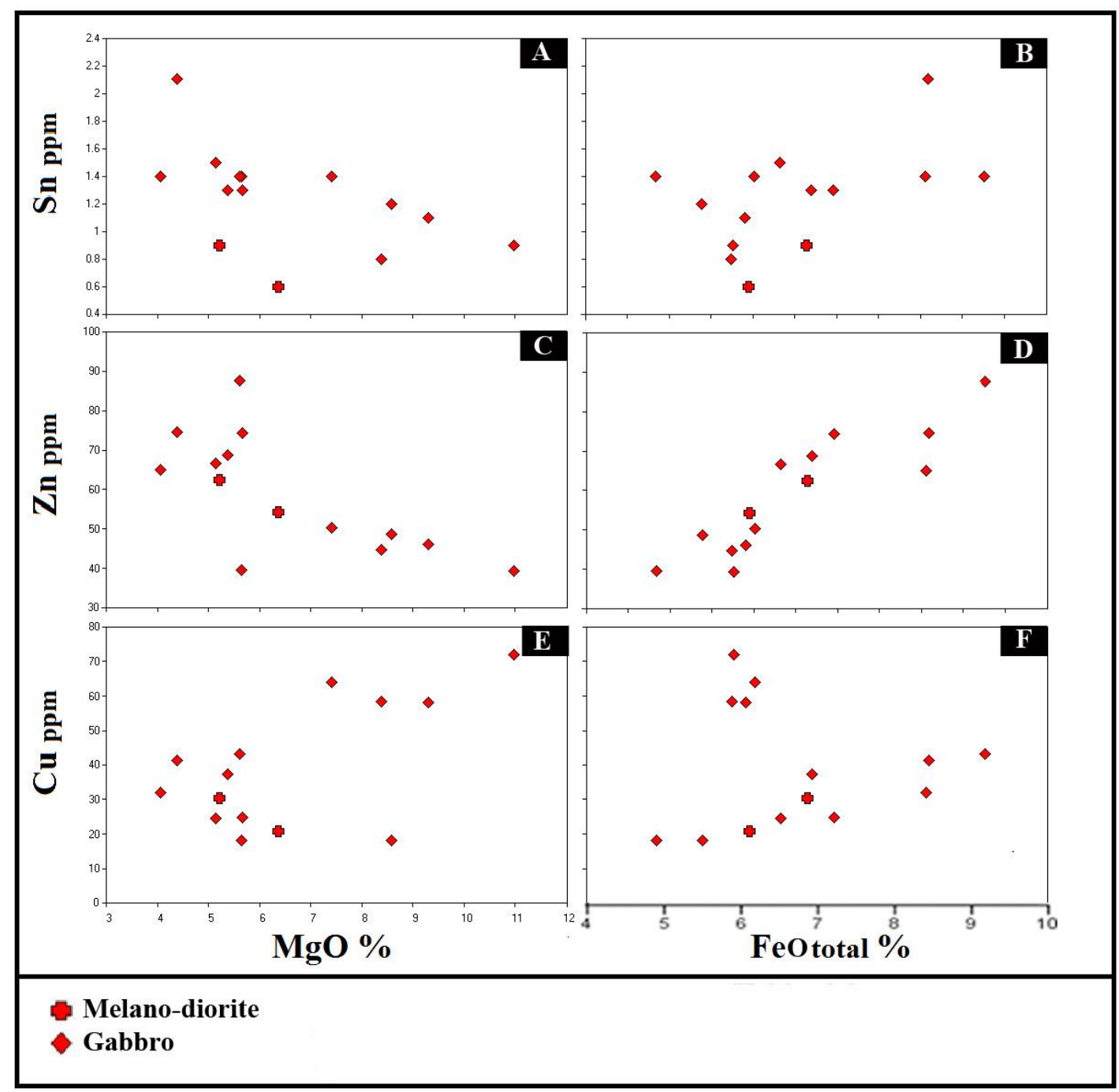

Fig. 9: Variation diagram of $\mathrm{MgO}$ and $\mathrm{FeO}_{\text {total }}$ vs. $\mathrm{Sn}, \mathrm{Zn}$, and $\mathrm{Cu}$ of pegmatites in the Bulfat complex.

\section{Rare Earth Elements (REEs):}

The pattern diagram of REEs after normalization with chondrite (Sun and McDonough, 1989) is accomplished (Table 5 and Fig.10).

Generally, The REEs are characterized by a relatively flat pattern (Fig. 10), this reflects the one origin. $\Sigma$ REEs range between $(55.34-153.75 \mathrm{ppm})$ (Table 6). The rates of LREEs and HREEs in these pegmatites range between (31.36-68.57 ppm) and (28.84$60.95 \mathrm{ppm}$ ) respectively (Table 6).

The ratio $(\mathrm{La} / \mathrm{Sm})_{\mathrm{N}}$ shows enrichment and depletion in LREE, this ratio ranges between (0.85-2.03) (Table 7). It is noted that this ratio is greater than one (except D3 A sample) (Table 7), which reflects the enrichment of these rocks in the LREEs content.

The ratio $(\mathrm{Gd} / \mathrm{Yb})_{\mathrm{N}}$ indicates the variation in HREEs content, this ratio ranges between (1.07-1.78) (Table 7) and these values reflect a limited variance, which explains the homogeneity and flatness in the HREEs. 
In general, the ratio $(\mathrm{La} / \mathrm{Yb})_{\mathrm{N}}$ shows the variation in the REEs behavior, as it indicates enrichment or depletion in LREEs relative to HREEs content, this ratio extends between (1.34-3.80) (Table 7) reflecting the enrichment of these rocks with LREEs compared to HREEs, whereas the ratio $(\mathrm{La} / \mathrm{Yb})_{\mathrm{N}}$ is consistent with the ratio $(\mathrm{La} / \mathrm{Sm})_{\mathrm{N}}$.

Moreover, an anomaly in the behavior of (Eu) element is observed in the REEs pattern, which can be illustrated by using the ratio (EuN / Eu*) through the equation $\mathrm{Eu}_{\mathrm{N}} / \mathrm{Eu}^{*}=(\mathrm{Eu})_{\mathrm{N}} /\left(\mathrm{Sm}_{\mathrm{N}}{ }^{*} \mathrm{Gd}_{\mathrm{N}}\right)^{0.5}$. Most samples show a small negative anomaly, indicating the fractionation of plagioclase (Zhang et al., 2003; Van Wagoner et al., 2002), while some samples show a positive anomaly, reflecting the accumulation of plagioclase as a result of the magmatic processes (Ottonello et al., 1984; Trubelja et al., 1995) (Table 7).

A negative correlation is observed between Mg\# and $\mathrm{R}$ REEs, where the REEs increase with the decrease of $\mathrm{Mg \#}$ and this is due to the fractionation process of the mafic minerals (Fig. 10).

Table 5: The concentrations of REEs in the pegmatites normalized with the same concentrations of chondrite elements from (Sun and McDonough, 1989).

\begin{tabular}{|c|c|c|c|c|c|c|c|c|c|c|c|c|c|c|c|}
\hline \multirow{2}{*}{ Samples } & \multicolumn{2}{|c|}{ Melano-diorite } & \multicolumn{12}{|c|}{ Gabbro } & \multirow{2}{*}{ Chondrite } \\
\hline & D7 & D7c & D2 $_{\mathrm{A}}$ & D2 $\mathrm{B}$ & $\mathbf{D 3}_{\mathbf{A}}$ & D3B & D3C & D5 $_{A}$ & D5 & D5c & D6A & D6в & D8 $_{A}$ & D8 & \\
\hline La & 37.975 & 26.582 & 35.021 & 30.380 & 22.785 & 32.489 & 34.177 & 55.274 & 35.865 & 42.194 & 43.882 & 56.962 & 82.700 & 97.046 & 0.237 \\
\hline Ce & 35.245 & 26.193 & 31.471 & 26.536 & 24.542 & 31.454 & 30.637 & 47.680 & 32.304 & 36.961 & 39.624 & 56.225 & 80.523 & 86.683 & 0.612 \\
\hline Pr & 36.842 & 27.368 & 28.421 & 25.263 & 27.368 & 31.579 & 32.632 & 42.105 & 29.474 & 33.684 & 31.579 & 54.737 & 74.737 & 80.000 & 0.095 \\
\hline Nd & 31.263 & 30.193 & 25.910 & 22.056 & 25.054 & 29.336 & 30.407 & 34.475 & 29.550 & 31.692 & 32.334 & 45.396 & 71.520 & 71.520 & 0.467 \\
\hline Sm & 30.065 & 19.608 & 26.797 & 20.915 & 26.797 & 28.105 & 22.876 & 30.065 & 21.569 & 27.451 & 21.569 & 37.255 & 47.059 & 50.980 & 0.153 \\
\hline Eu & 27.586 & 25.862 & 17.241 & 18.966 & 20.690 & 20.690 & 17.241 & 24.138 & 20.690 & 25.862 & 24.138 & 27.586 & 36.207 & 32.759 & 0.058 \\
\hline Gd & 23.301 & 19.903 & 17.961 & 18.932 & 24.272 & 22.330 & 22.816 & 21.845 & 16.505 & 24.272 & 19.903 & 25.243 & 38.835 & 35.437 & 0.206 \\
\hline $\mathbf{T b}$ & 24.324 & 21.622 & 16.216 & 16.216 & 18.919 & 21.622 & 21.622 & 21.622 & 16.216 & 21.622 & 21.622 & 24.324 & 29.730 & 35.135 & 0.037 \\
\hline Dy & 21.260 & 18.898 & 19.685 & 16.535 & 20.866 & 24.016 & 19.291 & 17.323 & 16.142 & 21.654 & 18.504 & 25.591 & 30.315 & 28.346 & 0.254 \\
\hline Ho & 19.298 & 17.544 & 17.544 & 15.789 & 17.544 & 17.544 & 15.789 & 19.298 & 15.789 & 19.298 & 19.298 & 24.561 & 26.316 & 29.825 & 0.057 \\
\hline $\mathbf{E r}$ & 18.072 & 18.675 & 14.458 & 16.265 & 16.265 & 19.880 & 20.482 & 18.072 & 14.458 & 16.265 & 18.072 & 22.289 & 21.687 & 22.892 & 0.166 \\
\hline Tm & 101.961 & 90.196 & 105.882 & 78.431 & 113.725 & 94.118 & 113.725 & 109.804 & 101.961 & 113.725 & 94.118 & 156.863 & 145.098 & 176.471 & 0.026 \\
\hline $\mathbf{Y b}$ & 15.294 & 13.529 & 15.882 & 11.765 & 17.059 & 14.118 & 17.059 & 16.471 & 15.294 & 17.059 & 14.118 & 23.529 & 21.765 & 26.471 & 0.17 \\
\hline Lu & 12 & 16 & 16 & 12 & 12 & 20 & 16 & 20 & 16 & 16 & 16 & 20 & 24 & 24 & 0.025 \\
\hline
\end{tabular}




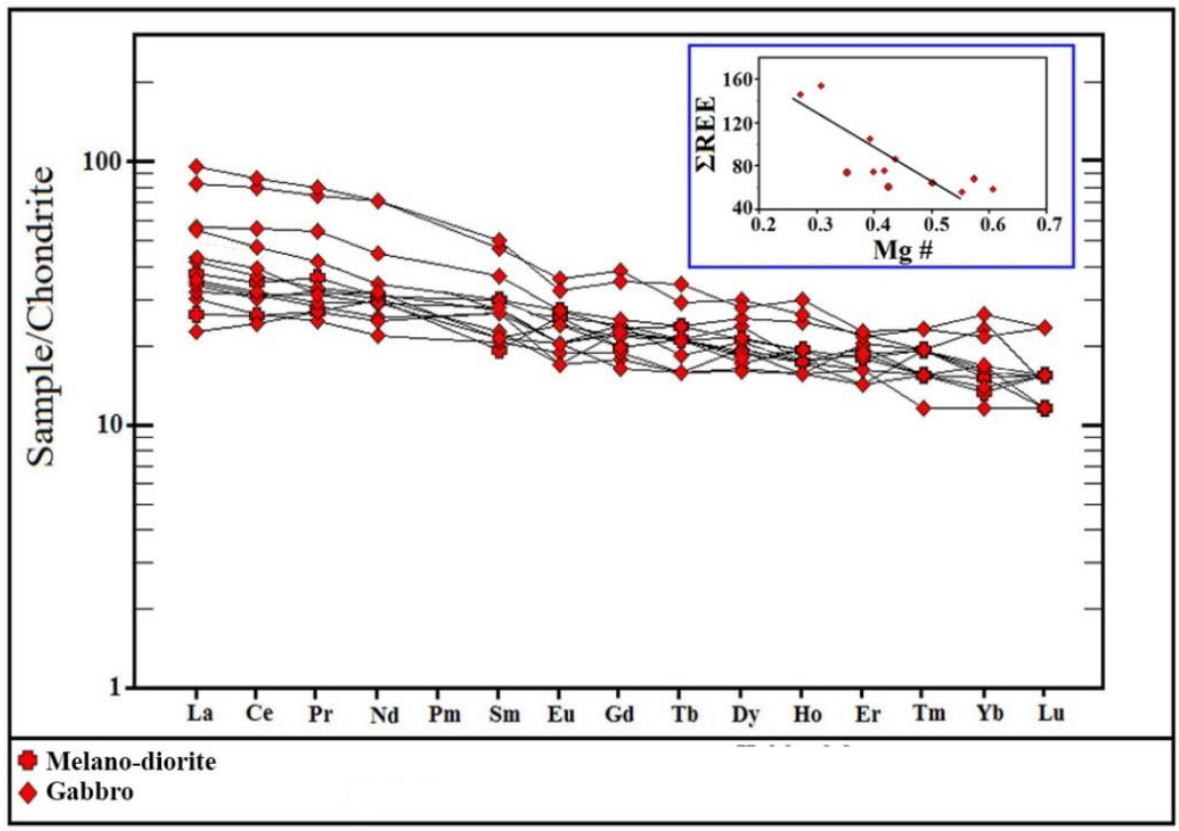

Fig. 10: Chondrite-normalized REEs diagram of pegmatites, data from (Sun and McDonough, 1989).

Table 6: Average concentrations and $\Sigma$ REEs of pegmatites normalized with the same concentrations of chondrite elements from (Sun and McDonough, 1989).

\begin{tabular}{|c|c|c|c|c|c|c|c|c|c|c|c|c|c|c|}
\hline & D7 & ${ }^{D} 7_{C}$ & $\mathrm{D2}_{\mathrm{A}}$ & D2 ${ }_{B}$ & $\mathbf{D 3}_{\mathrm{A}}$ & D3 $_{B}$ & D3C & D5 $_{\text {A }}$ & D5 $_{B}$ & ${ }^{D 5}{ }_{C}$ & D6 $_{A}$ & D6 $_{B}$ & D8 & D8 $_{B}$ \\
\hline LREE & 39.67 & 36.69 & 41.43 & 31.36 & 43.22 & 39.36 & 44.41 & 44.21 & 39.95 & 44.51 & 37.99 & 60.17 & 58.27 & 68.57 \\
\hline HREE & 36.07 & 33.69 & 36.93 & 28.84 & 38.73 & 36.11 & 40.42 & 39.85 & 35.70 & 39.80 & 34.67 & 53.86 & 52.17 & 60.95 \\
\hline IREE & 73.47 & 60.43 & 63.76 & 55.34 & 58.32 & 68.25 & 67.15 & 85.98 & 64.17 & 75.12 & 74.35 & 104.3 & 145.5 & 153.8 \\
\hline
\end{tabular}

Table 7: The ratios of REEs of pegmatites normalized with the same concentrations of chondrite elements from (Sun and McDonough, 1989).

\begin{tabular}{l|ccccccccccccccc}
\hline & & & & & & & & & & \\
\hline
\end{tabular}




\section{Spider diagram:}

The spider diagram is accomplished after normalization with primitive mantle (Sun and McDonough, 1989) (Table 8).

The spider diagram of the studied pegmatites (Fig. 11) shows a positive anomaly in $\mathrm{Sr}, \mathrm{Pb}$, and $\mathrm{Rb}$ elements in most samples relative to neighboring REEs (Table 9), with a noticeable flatness in the pattern from $\mathrm{Zr}$ to $\mathrm{Sm}$. While $\mathrm{Y}, \mathrm{Ta}$, and $\mathrm{Nb}$ elements show a negative anomaly in most samples relative to adjacent REEs (Table 9), this anomaly reflects the island arcs environment (Aswad et al., 2013).

Generally, the ratios of $(\mathrm{Rb} / \mathrm{Sr})_{\mathrm{N}}$ and $(\mathrm{Ba} / \mathrm{Sr})_{\mathrm{N}}$ are low in these rocks (Table 9), which suggests that these pegmatites are derived from a basic origin, whereas the high ratios of $(\mathrm{Rb} / \mathrm{Sr})_{\mathrm{N}}$ and $(\mathrm{Ba} / \mathrm{Sr})_{\mathrm{N}}$ refer to a non-basic origin (Rogers and Greenberg, 1990).

Table 8: The concentrations of the elements in the pegmatites normalized with the same concentrations of primitive mantle elements (P.M) from (Sun and McDonough, 1989).

\begin{tabular}{|c|c|c|c|c|c|c|c|c|c|c|c|c|c|c|c|}
\hline \multirow{2}{*}{$\begin{array}{c}\text { Rocks } \\
\text { Samples }\end{array}$} & \multicolumn{2}{|c|}{ Melano-diorite } & \multicolumn{12}{|c|}{ Gabbro } & \multirow{2}{*}{ P.M } \\
\hline & D7 & D7 $C$ & D2 ${ }_{A}$ & D2 ${ }_{B}$ & $\mathbf{D 3}_{\mathrm{A}}$ & $\mathbf{D 3}_{\mathbf{B}}$ & D3C $_{C}$ & D5 $_{A}$ & D5 & D5C $_{C}$ & D6 $_{A}$ & D6в & D8 $_{A}$ & D8B & \\
\hline Cs & 14.286 & 33.333 & 85.714 & 19.048 & 19.048 & 23.810 & 47.619 & 242.857 & 57.143 & 57.143 & 47.619 & 33.333 & 42.857 & 9.524 & 0.02 \\
\hline $\mathbf{R b}$ & 58.167 & 21.333 & 42.167 & 38.500 & 24.833 & 23.333 & 27.667 & 59.167 & 31.833 & 53.667 & 34.667 & 35.000 & 40.667 & 29.167 & 0.60 \\
\hline $\mathbf{B a}$ & 16.212 & 12.273 & 14.394 & 11.970 & 5.758 & 9.091 & 10.758 & 24.091 & 13.788 & 17.121 & 17.121 & 19.091 & 15.909 & 6.818 & 6.60 \\
\hline Th & 13.836 & 7.547 & 17.610 & 21.384 & 10.063 & 13.836 & 17.610 & 22.642 & 17.610 & 20.126 & 27.673 & 27.673 & 20.126 & 65.409 & 0.08 \\
\hline $\mathbf{U}$ & 14.778 & 9.852 & 19.704 & 24.631 & 9.852 & 14.778 & 19.704 & 24.631 & 14.778 & 24.631 & 29.557 & 19.704 & 19.704 & 49.261 & 0.02 \\
\hline $\mathbf{K}$ & 33.241 & 15.374 & 24.931 & 19.945 & 14.959 & 17.036 & 18.698 & 38.228 & 20.360 & 31.579 & 21.191 & 22.853 & 22.853 & 15.790 & 0.03 \\
\hline $\mathrm{Nb}$ & 5.897 & 3.207 & 7.508 & 5.486 & 3.526 & 5.775 & 6.140 & 13.343 & 6.672 & 9.286 & 10.076 & 13.799 & 3.632 & 5.046 & 0.66 \\
\hline $\mathbf{T a}$ & 8.108 & 8.108 & 10.811 & 10.811 & 8.108 & 16.216 & 10.811 & 13.514 & 10.811 & 16.216 & 32.432 & 16.216 & 5.405 & 8.108 & 0.04 \\
\hline La & 13.889 & 9.722 & 12.809 & 11.111 & 8.333 & 11.883 & 12.500 & 20.216 & 13.117 & 15.432 & 16.049 & 20.833 & 30.247 & 35.494 & 0.65 \\
\hline $\mathrm{Ce}$ & 12.878 & 9.570 & 11.499 & 9.696 & 8.967 & 11.493 & 11.194 & 17.421 & 11.803 & 13.504 & 14.478 & 20.543 & 29.421 & 31.672 & 1.68 \\
\hline $\mathbf{P b}$ & 25.133 & 13.067 & 34.400 & 30.867 & 27.733 & 28.000 & 25.667 & 35.800 & 24.933 & 23.000 & 29.800 & 31.267 & 15.133 & 30.800 & 0.15 \\
\hline $\operatorname{Pr}$ & 14.000 & 10.400 & 10.800 & 9.600 & 10.400 & 12.000 & 12.400 & 16.000 & 11.200 & 12.800 & 12.000 & 20.800 & 28.400 & 30.400 & 0.25 \\
\hline $\mathrm{Sr}$ & 21.055 & 21.910 & 18.291 & 13.668 & 9.598 & 12.915 & 14.422 & 23.015 & 19.347 & 22.161 & 24.271 & 19.548 & 23.518 & 16.332 & 19.9 \\
\hline Nd & 11.680 & 11.280 & 9.680 & 8.240 & 9.360 & 10.960 & 11.360 & 12.880 & 11.040 & 11.840 & 12.080 & 16.960 & 26.720 & 26.720 & 1.25 \\
\hline $\mathrm{Zr}$ & 11.124 & 9.429 & 10.276 & 9.429 & 9.219 & 11.981 & 11.400 & 15.619 & 11.324 & 12.476 & 12.952 & 13.924 & 22.819 & 27.505 & 10.5 \\
\hline Hf & 12.120 & 11.237 & 9.717 & 10.177 & 10.883 & 11.767 & 11.484 & 13.039 & 10.353 & 11.449 & 11.201 & 13.463 & 22.085 & 27.138 & 0.28 \\
\hline Sm & 11.330 & 7.389 & 10.099 & 7.882 & 10.099 & 10.591 & 8.621 & 11.330 & 8.128 & 10.345 & 8.128 & 14.039 & 17.734 & 19.212 & 0.41 \\
\hline $\mathbf{E u}$ & 10.390 & 9.740 & 6.494 & 7.143 & 7.792 & 7.792 & 6.494 & 9.091 & 7.792 & 9.740 & 9.091 & 10.390 & 13.636 & 12.338 & 0.15 \\
\hline Gd & 8.889 & 7.593 & 6.852 & 7.222 & 9.259 & 8.519 & 8.704 & 8.333 & 6.296 & 9.259 & 7.593 & 9.630 & 14.815 & 13.519 & 0.54 \\
\hline $\mathbf{T b}$ & 9.091 & 8.081 & 6.061 & 6.061 & 7.071 & 8.081 & 8.081 & 8.081 & 6.061 & 8.081 & 8.081 & 9.091 & 11.111 & 13.131 & 0.10 \\
\hline Dy & 8.012 & 7.122 & 7.418 & 6.231 & 7.864 & 9.050 & 7.270 & 6.528 & 6.083 & 8.160 & 6.973 & 9.644 & 11.424 & 10.682 & 0.67 \\
\hline $\mathbf{T i}$ & 9.025 & 6.548 & 6.614 & 5.458 & 5.904 & 5.813 & 5.516 & 6.507 & 5.400 & 9.752 & 7.845 & 10.107 & 10.388 & 8.646 & 0.20 \\
\hline $\mathbf{Y}$ & 6.651 & 6.000 & 5.837 & 4.977 & 6.279 & 6.442 & 6.419 & 6.814 & 5.372 & 6.140 & 6.070 & 8.302 & 9.070 & 9.698 & 4.30 \\
\hline Ho & 7.383 & 6.711 & 6.711 & 6.040 & 6.711 & 6.711 & 6.040 & 7.383 & 6.040 & 7.383 & 7.383 & 9.396 & 10.067 & 11.409 & 0.15 \\
\hline $\mathbf{E r}$ & 6.849 & 7.078 & 5.479 & 6.164 & 6.164 & 7.534 & 7.763 & 6.849 & 5.479 & 6.164 & 6.849 & 8.447 & 8.219 & 8.676 & 0.44 \\
\hline $\mathbf{T m}$ & 7.776 & 6.221 & 7.776 & 4.666 & 6.221 & 6.221 & 7.776 & 7.776 & 6.221 & 6.221 & 6.221 & 7.776 & 9.331 & 9.331 & 0.06 \\
\hline $\mathbf{Y b}$ & 5.896 & 5.215 & 6.122 & 4.535 & 6.576 & 5.442 & 6.576 & 6.349 & 5.896 & 6.576 & 5.442 & 9.070 & 8.390 & 10.204 & 0.44 \\
\hline $\mathbf{L u}$ & 4.444 & 5.926 & 5.926 & 4.444 & 4.444 & 7.407 & 5.926 & 7.407 & 5.926 & 5.926 & 5.926 & 7.407 & 8.889 & 8.889 & 0.07 \\
\hline
\end{tabular}




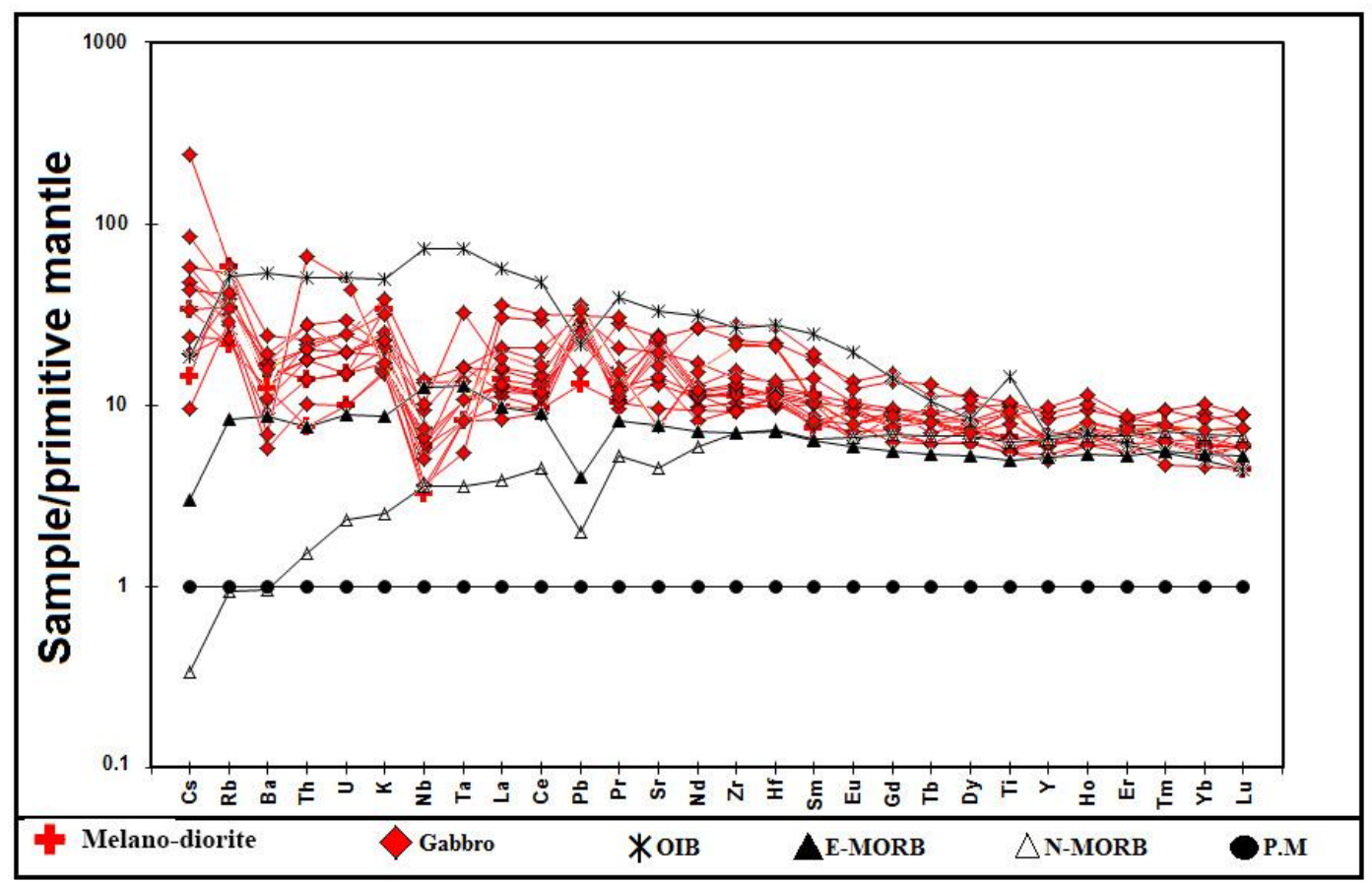

Fig. 11: Spider diagram of the elements in the pegmatites after normalization with the same concentrations of primitive mantle elements (P.M) from (Sun and McDonough, 1989).

Table 9: The ratios of the elements in the pegmatites normalization with the same concentrations of primitive mantle elements from (Sun and McDonough, 1989).

\begin{tabular}{|c|c|c|c|c|c|c|c|c|c|}
\hline Samples & $(\mathbf{R b} / \mathbf{L a})_{\mathrm{N}}$ & $(\mathbf{B a} / \mathbf{L a})_{\mathrm{N}}$ & $(\mathbf{N b} / \mathbf{L a})_{\mathbf{N}}$ & $(\mathrm{Ta} / \mathrm{La})_{\mathrm{N}}$ & $(\mathrm{Pb} / \mathrm{Ce})_{\mathrm{N}}$ & $(\mathbf{S r} / \mathbf{N d})_{\mathbf{N}}$ & $(\mathbf{Y} / \mathbf{H o})_{\mathbf{N}}$ & $(\mathbf{R b} / \mathbf{S r})_{\mathrm{N}}$ & $(\mathbf{B a} / \mathbf{S r})_{\mathrm{N}}$ \\
\hline $\mathbf{D}_{7_{\mathrm{B}}}$ & 4.188 & 1.167 & 0.425 & 0.584 & 1.952 & 1.803 & 0.901 & 2.763 & 0.770 \\
\hline D7 $\mathrm{C}$ & 2.194 & 1.262 & 0.330 & 0.834 & 1.365 & 1.942 & 0.894 & 0.974 & 0.560 \\
\hline $\mathbf{D} \mathbf{2}_{\mathrm{A}}$ & 3.292 & 1.124 & 0.586 & 0.844 & 2.992 & 1.890 & 0.870 & 2.305 & 0.787 \\
\hline D2 B $_{B}$ & 3.465 & 1.077 & 0.494 & 0.973 & 3.184 & 1.659 & 0.824 & 2.817 & 0.876 \\
\hline $\mathbf{D 3}_{\mathrm{A}}$ & 2.980 & 0.691 & 0.423 & 0.973 & 3.093 & 1.025 & 0.936 & 2.587 & 0.600 \\
\hline $\mathbf{D}_{\mathbf{B}_{\mathrm{B}}}$ & 1.964 & 0.765 & 0.486 & 1.365 & 2.436 & 1.178 & 0.960 & 1.807 & 0.704 \\
\hline${ }^{D} 3_{C}$ & 2.213 & 0.861 & 0.491 & 0.865 & 2.293 & 1.270 & 1.063 & 1.918 & 0.746 \\
\hline $\mathrm{D5}_{\mathrm{A}}$ & 2.927 & 1.192 & 0.660 & 0.668 & 2.055 & 1.787 & 0.923 & 2.571 & 1.047 \\
\hline D5 $_{B}$ & 2.427 & 1.051 & 0.509 & 0.824 & 2.112 & 1.752 & 0.889 & 1.645 & 0.713 \\
\hline $\mathbf{D 5}_{\mathrm{C}}$ & 3.478 & 1.109 & 0.602 & 1.051 & 1.703 & 1.872 & 0.832 & 2.422 & 0.773 \\
\hline D6A & 2.160 & 1.067 & 0.628 & 2.021 & 2.058 & 2.009 & 0.822 & 1.428 & 0.705 \\
\hline D6 $_{B}$ & 1.680 & 0.916 & 0.662 & 0.778 & 1.522 & 1.153 & 0.884 & 1.790 & 0.977 \\
\hline D8 $_{A}$ & 1.344 & 0.526 & 0.120 & 0.179 & 0.514 & 0.880 & 0.901 & 1.729 & 0.676 \\
\hline $\mathrm{D8}_{\mathrm{B}}$ & 0.822 & 0.192 & 0.142 & 0.228 & 0.972 & 0.611 & 0.850 & 1.786 & 0.417 \\
\hline
\end{tabular}

\section{DISCUTION AND CONCLUSIONS}

During the last three decades, many researchers have used various geochemical methods to isolate tectonic environments from each other depending on binary and ternary variation diagrams known as tectonic discriminate diagrams, by relying on some of the major, trace, and rare earth elements. 
Figure (12A) shows that the studied pegmatites are of igneous origin (I-type). The $\mathrm{SiO}_{2}-\mathrm{K}_{2} \mathrm{O}$ diagram explains the evolution of the volcanic arc from tholeiite to shoshonite, this diagram shows the presence of these pegmatites in the calc-alkaline field (Fig. 12B), which are sub alkaline rocks (Fig. 12C). The studied pegmatites in the mentioned diagrams are consistent with the intrusive rocks close to the study area that are gabbros of Wadi Rashid studied by Aswad et al (2013).

Using $(\mathrm{Ta} / \mathrm{Yb})$ against $(\mathrm{Th} / \mathrm{Yb})$ of (Pearce, 1982) to sort between volcanic arc basalts (VAB), mid oceanic ridge basalts (MORB), and within plate basalts (WPB), the studied pegmatites veer from MORB field and occur in VAB field of calc-alkaline type (CA) (Fig. 12D). The tectonic discriminate diagrams (Hf-Th-Ta) and (Nb-Zr-Y) (Fig. $13 \mathrm{~A}, \mathrm{~B})$ show most pegmatites are located in the volcanic arc basalts field. Moreover, Fig.(13) shows some samples are located in MORB; this indicates that these rocks were erupted in an extensional stress regime (Aswad et al., 2013). Nevertheless, Fig. 13 emphasizes the volcanic arc environment of studied pegmatites. The $\mathrm{SiO}_{2}-\mathrm{K}_{2} \mathrm{O} / \mathrm{Na}_{2} \mathrm{O}$ diagram (Fig. 14) shows that the environment of studied pegmatites is oceanic island arcs.

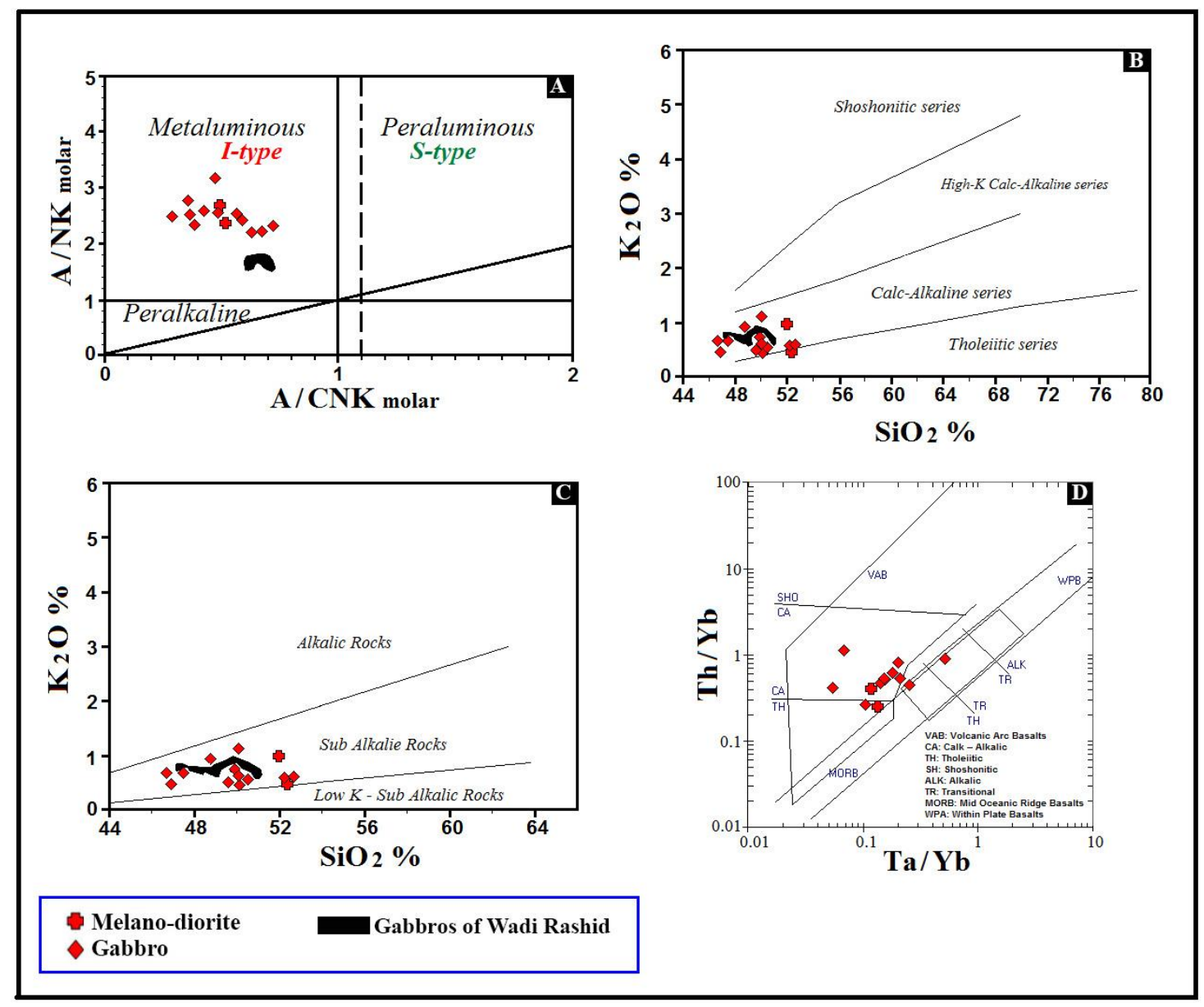

Fig. 12: Tectonic environment of the studied pegmatites. A: The molar relationship between $\mathrm{A} / \mathrm{NK}$ and $\mathrm{A} / \mathrm{CNK}$ for sorting between the type of alumina saturation from (Maniar and Piccoli, 1989) and type of rocks from (Chappell and White, 1974). $\mathbf{B}$ and $\mathbf{C}: \mathrm{SiO}_{2}$ vs. $\mathrm{K}_{2} \mathrm{O}$ diagram to distinguish the type of pegmatites from (Peccerillo and Taylor, 1976) and (Middlemost, 1975) respectively. D: Ta/Yb vs. Th/Yb diagram to distinguish tectonic of the studied pegmatites from (Pearce, 1982). In comparison with gabbros of Wadi Rashid from 


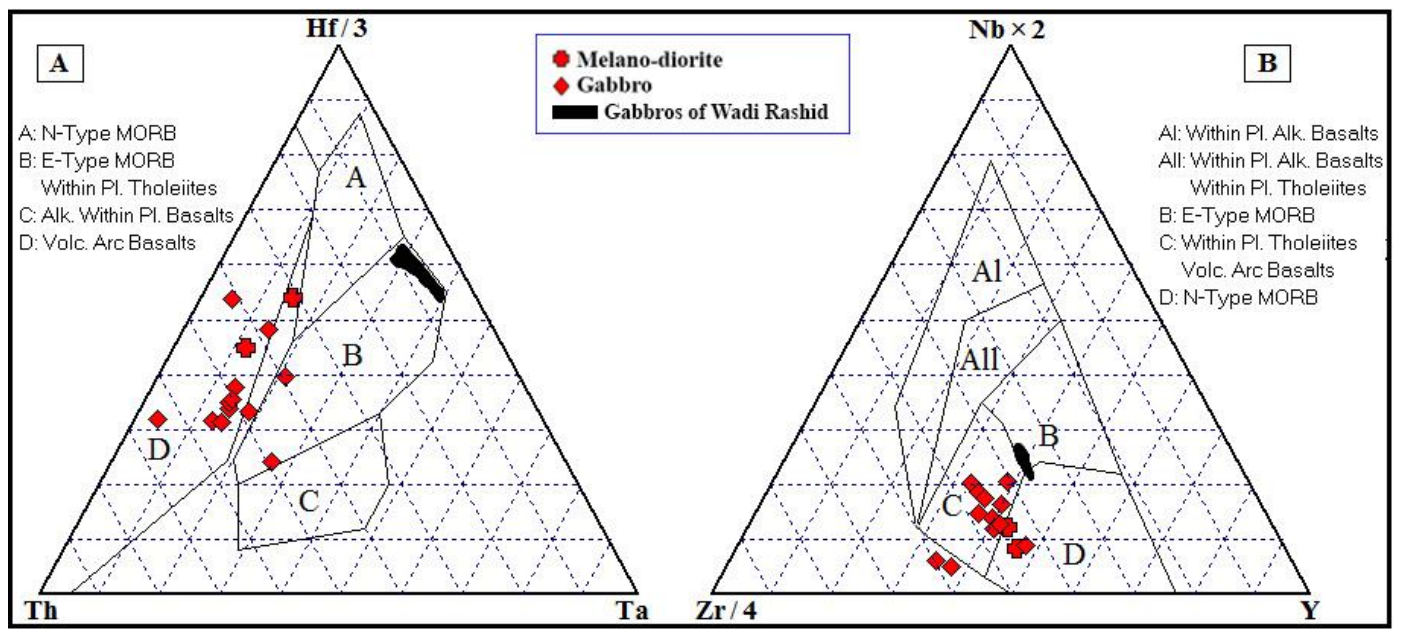

Fig. 13: Tectonic discriminate ternary diagrams of the studied pegmatites. A: from (Wood, 1980). B: from (Pearce, 1982). In comparison with gabbros of Wadi Rashid from (Aswad et al., 2013).

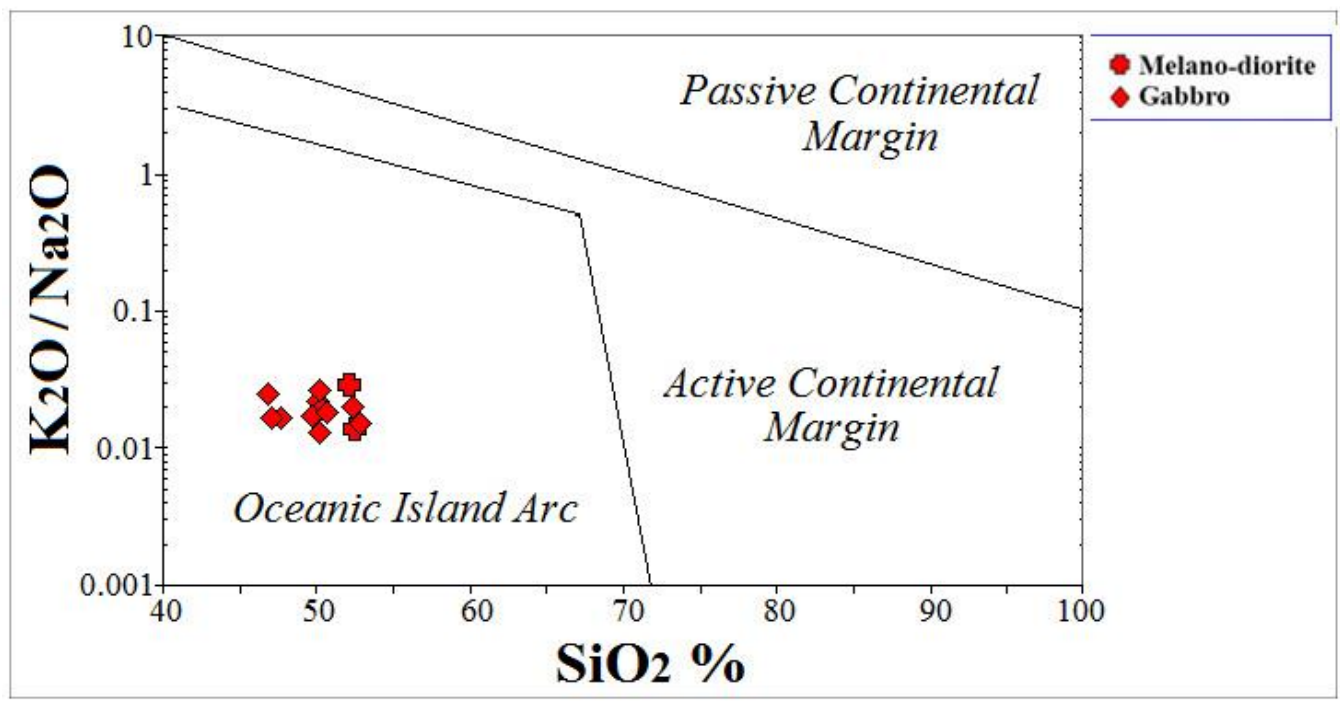

Fig. 14: $\mathrm{SiO}_{2}$ vs. $\mathrm{Log}\left(\mathrm{K}_{2} \mathrm{O} / \mathrm{Na}_{2} \mathrm{O}\right)$ diagram to characterize the tectonic environment of the studied pegmatites, modified from (Bathia, 1983).

The relatively flat pattern of REEs is characterized by the enrichment of LREEs compared to HREEs (Fig. 10) indicating the common ancestry origin of the studied pegmatites. Also, the enrichment in LILEs ( $\mathrm{Sr}, \mathrm{Pb}, \mathrm{Rb}$ ) and depletion in HFSEs especially $(\mathrm{Nb}, \mathrm{Ta}, \mathrm{Y})$ (Fig. 11) indicate the environment of the island arcs. The enrichment of LILEs is due to their migration by aqueous solutions derived from the subducted oceanic slab to the mantle wedge above it by dehydration, and an indication of the added fluids from the subducted slab to the mantle wedge (Breeding et al., 2004), whereas the HFSEs are immobile through these solutions and remain in the subducted oceanic slab (Breeding et al., 2004). In addition, the pegmatitic melt crystallizes far from equilibrium (Chakoumakos and Lumpkin, 1990; Morgan and London, 1999; Webber et al., 1999). Therefore, the difference occurs in the fractionation and behavior of LILEs from what is expected in other melts (London, 2005b). Moreover, the low ratios of 
$(\mathrm{Rb} / \mathrm{Sr})_{\mathrm{N}}$ and $(\mathrm{Ba} / \mathrm{Sr})_{\mathrm{N}}$ refer to that these pegmatites are derived from a basic origin (Rogers and Greenberg, 1990).

The previously presented tectonic discriminate diagrams show that the tectonic environment of the studied pegmatites is I-type, which is the oceanic island arcs environment of sub alkaline rocks. The pegmatites of the present study have a genesis relationship with intrusions close to them in the study area, these intrusions are gabbros of Wadi Rashid that represent the environment of E-MORB (Aswad et al., 2013) and the age of these intrusions is $40 \mathrm{Ma}$ (Aswad et al., 2016). The gabbros of Wadi Rashid and studied pegmatites are part of ophiolite-bearing terranes (Aswad et al., 2011), they are found within upper allochthon thrust sheet of Albian-Cenomenian (Aswad and Elias, 1988; Aswad, 1999). In addition, there are volcanic arc activities in the lower allochthon of Palaeogene, represented by walash volcanic (basic rocks) that have island arcs environment type island arc tholeiite (IAT) and calc-alkaline basalt (CAB) having the age between 32-43 Ma (Koyi, 2006). Whereas, the current study of pegmatites reflects the oceanic island arcs environment, this indicates the existence of double island arcs, the first adjacent to the Arabian shelf, and the second close to the middle of paleo-ridge.

Numerous evidences support the gabbros of Wadi Rashid as the likely parent to the studied pegmatites such as geochemistry, tectonogenesis, and the close spatial distribution of the pegmatites to the gabbros of Wadi Rashid. Moreover, the studied pegmatites appear to entail further dissection mainly due to the fact that the occurrence of dioritic- and gabbroic-pegmatites with a small-scale in the single intrusion might have its explanation in the liquid associated immiscibility.

\section{REFERENCES}

Al-Hamed, S. T., Aswad, K. J., and Aziz, N. R., 2019. Classification of Composite Pegmatite via Staining and Digital Image Processing in the Bulfat Complex, Qala Diza, NE (Iraq). In: Doronzo D., Schingaro E., Armstrong-Altrin J., Zoheir B. (eds) Petrogenesis and Exploration of the Earth's Interior. Advances in Science, Technology \& Innovation (IEREK Interdisciplinary Series for Sustainable Development). Springer, Cham.

Aswad, K. J., 1999. Arc-continental collision in Northeastern Iraq as evidence by the Mawat and Penjwen ophiolite complex. Raf. Jour. Sci, Vol. 10, pp. 51-61.

Aswad, K. J., and Elias, E. M., 1988. Petrogenesis, geochemistry and metamorphism of spilitized subvolcanic rocks of the Mawat ophiolite complex, NE Iraq. Ofioliti., Vol. 13, pp. 95-109.

Aswad, K. J, Al.Sheraefy R. M., and Ali S. A., 2013. Pre-collisional Intrusive Magmatism in the Bulfat Complex, Wadi Rashid, Qala Diza, NE Iraq: Geochemical and Mineralogical Constraints and Implications for Tectonic Evolution of Granitoid-gabbro Suites, Iraqi National Journal of Earth Sciences, Vol. 13, pp. 103-137.

Aswad, K. J. A., Aziz, N. R. H., and Koyi, H. A., 2011. Cr-spinel compositions in serpentinites and their implications for the petrotectonic history of Zagros Suture Zone, Kurdistan Region, Iraq. Geological Magazine, pp. 1-17. 
Aswad, K. J., Ali, S. A., Al-sheraefy, R. M., Nutman, A. P., Jones, B. G., Buckman, S., and Jourdand, F., 2016. 40Ar/39Ar hornblende and biotite geochronology of the Bulfat Igneous Complex, Zagros Suture Zone, NE-Iraq: new insights on complexities of Paleogene arc magmatism during closure of the Neotethys Ocean. Lithos 266-267, pp. 406-413.

Bathia, M. R., 1983. Plate tectonics and geochemical composition of sandstones. Journal Geology, Vol. 91, pp. 611-627.

Breeding, C. M., Ague, J. J., and Brocker, M., 2004. Fluid metasedimentary interactions in subduction zone mélange: implications for the chemical composition of arc magma, Geology, Vol. 32, pp. 1041-1044.

Buda, G., 1993. Igneous petrology of the Bulfat area (NE Iraqi Zagros thrust zone). Acta Mineral Petrogr Vol. 34, pp. 21-39.

Buday, T., and Jassim, S. Z., 1987. The regional geology of Iraq, Vol. 2, Tectonism, Magmatism and Metamorphism (eds.) Kassab, I. M. and Abass, M. J., Geological Survey and Mineral Investigation, Baghdad, Iraq., 352p.

Buday, T., and Suk, M., 1978. Report on the geological survey in NE Iraq between Halabja and Qala-Diza, Unpubl. Report, NIMCO Lib., Baghdad.

Chakoumakos, B. C., Lumpkin, G. R., 1990. Pressure-temperature constraints on the crystallization of the Harding pegmatite, Taos County, New Mexico. Canadian Mineralogist, Vol. 28, pp. 287-298.

Chappell, B. W., and White, A. J. R., 1974. Two contrasting granite types. Pacifu Geology, Vol. 8, pp. 173-174.

Jassim, S. Z., Buda, G., Neuzilova, M., and Suk, M., 1982a. Metamporphic development of the Iraqi Zagros ophiolitic zone. Academia publishing House of the Czechoslovak Academy of Science, Krystalinikum, Vol. 16, pp. 21-40.

Jassim, S. Z., Waldhausrova, J., and Suk, M., 1982b. Evolution of magmatic activity in Iraqi Zagros complexes. Academia publishing house of the Czechoslovak Academy of Science, Krystalinikum, Vol. 16, pp. 87-108.

Jassim, S.Z., Suk, M., and Waldhausrova, J., 2006a. Magmatisim and metamorphism in the Zagros Suture. In: S. Z. Jassim and J. C. Goff (eds), Geology of Iraq. Dolin, Prague and Moravian Museum, Brno, pp. 212-231.

Jassim, S. Z., Buday, T., Cicha, I., and Opletal, M., 2006b. Tectonostratigraphy of the Zagros Suture. In: S. Z. Jassim and J. C. Goff (eds), Geology of Iraq. Dolin, Prague and Moravian Museum, Brno, pp. 199-211.

Koyi, A. M., 2006. Petrochemistry, Petrogenesis and Isotope Dating of Walash Volcanic Rocks at Mawat - Chowarta Area, NE Iraq. Unpablished M.Sc. Thesis, University of Mosul, Iraq. 227p.

Linnen, R. L., Lichtervelde, M. V., Černý, P., 2012. Granitic Pegmatites as Sources of Strategic Metals. ELEMENTS, Vol. 8, PP. 275-280.

London, D., 2005a. Geochemistry of Alkali and Alkaline Earth Elements in OreForming Granites, Pegmatites, and Rhyolites, In: Linnen, R. L. and Sampson, I.M. Rare-Element Geochemistry and Mineral Deposits, pp. 175-199. 
London, D., 2005b. Granitic pegmatites: an assessment of current concepts and directions for the future. Lithos, Vol. 80, pp. 281-303.

Maniar, P. D., and Piccoli, P. M., 1989. Tectonic discrimination of granitoids. Geology Society of America Bulletin, Vol. 101, pp. 635-643.

Mason, B., and Moore, C.B., 1982: Principles of Geochemistry ( $4^{\text {th. }}$ Ed), John Wiley and Sons, 344p.

Middlemost, E. A. K., 1975. The basalt clan. Earth Science Reviews, Vol. 11, pp. 337364.

Morgan VI, G. B., London, D., 1999. Crystallization of the Little Three layered pegmatite-aplite dike, Ramona District, California. Contributions to Mineralogy and Petrology, Vol. 136, pp. 310-330.

Ottonello, G., Piccardo, G. B., and Joron, J. L., 1984. Rare earth and 3d transition element geochemistry of peridotitic rocks: II. Ligurian peridotites and associated basalts. Journal of Petrology, Vol. 25, pp. 379-393.

Pearce, J. A., 1982. Trace element characteristics of lavas from destructive plate boundaries (eds.) Thorpe, R.S., Andesites. Elsevier, pp.525-548.

Peccerillo, A., and Tylor, S. R., 1976. Geochemistry of Eocene calc-alkaline volcanic rocks from the Kastamonu area, Northern Turkey. Contributions to Mineralogy and Petrology, Vol. 58, pp. 63-81.

Rogers, J. J. W., and Greenberg, J. K., 1990. Late-orogenic, Postorogenic and anorogenic granites: distinction by major elements and trace elements chemistry and possible origins. Journal Geology, Vol. 98, no. 3, pp. 291-309.

Rollinson, H., 1993. Using geochemical data evolution, presentation, and interpretation; Wiley, New York, 351p.

Shawna, M., Leatherdale, Maxeiner, R. O., and Ansdell, K. M., 2003.Petrography and geochemistry of Love Lake lecogabbro, Swan River complex,Peter lake domain, northern Jour. Saskatchewan, Saskatchewan Geological Survey, Vol. 2, pp. 117.

Sofy, M. M., 2003. Petrochemistry and petrogenesis of Bulfat mafic layered igneous intrusion around Herro (Qaladizeh)-Iraq Kurdistan, Msc, thesis, Salahaddin University-Erbil, 123p.

Sun, S., and McDonough, W., 1989. Chemical and isotopic systematics of oceanic basalts: implications for mantle composition and processes. In: Saunders, A. D. and Norry, M. J. (eds.) Magmatism in the Ocean Basins. Geol. Soc. London., Special publication, Vol. 42, pp. 313-345.

Trubelja, F., Marchig, V., Burgath, K. P., and Vujović, Ž., 1995. Origin of the Jurassic Tethyan ophiolites in Bosnia: a geochemical approach to tectonic setting. Geol. Croatica, 48/1, 49-66, Zagreb. Unwin Hyman, London, 400 P.

Van Wagoner, N. A., Leybourne, M. I., Dadd, K. A., Baldwin, D .K., and McNeil, W., 2002. Late Silurian bimodal volcanism of Southwestern New Brunswick, Canada: Products of continental extension. GSA Bulletin, Vol. 114 (no.4), pp. 400-418. 
Webber, K. L., Simmons, W. B., Falster, A. U., Foord, E. E., 1999. Cooling rates and crystallization dynamics of shallow level pegmatite-aplite dikes, San Diego County, California. American Mineralogist, Vol. 84, pp. 708-717.

Wilson, M., 1989. Igneous Petrogenesis, A Global Tectonic Approach. Unwin Hyman, London, $400 \mathrm{P}$.

Wodepohl, K. H., 1978: Handbook of Geochemistry. Springer-Verlag Berlin Heidelberg, New York, Vol.II (no.5), 92p.

Wood, D. A., 1980. The application of a Th-Hf-Ta diagram to problems of tectonomagmatic classification and to establishing the nature of crustal contamination of basaltic lavas of the British Tertiary volcanic province: Earth and Planetary Science Letters, Vol. 50, pp. 11-30.

Zhang, Z., Mao, J., Paul, R. T., Mei, F. Z., Zao, G., Yang, J., Wang, Z., and Zhang, Z., 2003. The Aoyougou mafic-ultramafic complex in the North Qilian Mountains, Northwest China: A possible Middle Proterozoic ophiolite along the Southern Margin of the North China Craton. International Geology Review, Vol. 45, pp. $1-16$. 